\section{Pacific Northwest}

National Laboratory

Operated by Battelle for the

U.S. Department of Energy

\title{
Relative Hazard and Risk Measure Calculation Methodology
}

\author{
R.D. Stenner \\ W.B. Andrews \\ D.L. Strenge \\ M.S. Elder \\ T.L. Walton
}

September 2003

Prepared for the U.S. Department of Energy

under Contract DE-AC06-76RL01830 


\title{
DISCLAIMER
}

This report was prepared as an account of work sponsored by an agency of the United States Government. Neither the United States Government nor any agency thereof, nor Battelle Memorial Institute, nor any of their employees, makes any warranty, express or implied, or assumes any legal liability or responsibility for the accuracy, completeness, or usefulness of any information, apparatus, product, or process disclosed, or represents that its use would not infringe privately owned rights. Reference herein to any specific commercial product, process, or service by trade name, trademark, manufacturer, or otherwise does not necessarily constitute or imply its endorsement, recommendation, or favoring by the United States Government or any agency thereof, or Battelle Memorial Institute. The views and opinions of authors expressed herein do not necessarily state or reflect those of the United States Government or any agency thereof.

\author{
PACIFIC NORTHWEST NATIONAL LABORATORY \\ operated by \\ BATTELLE \\ for the \\ UNITED STATES DEPARTMENT OF ENERGY \\ under Contract DE-AC06-76RL01830 \\ Printed in the United States of America \\ Available to DOE and DOE contractors from the \\ Office of Scientific and Technical Information, \\ P.O. Box 62, Oak Ridge, TN 37831-0062; \\ ph: (865) 576-8401 \\ fax: (865) $576-5728$ \\ email: reports@adonis.osti.gov \\ Available to the public from the National Technical Information Service, \\ U.S. Department of Commerce, 5285 Port Royal Rd., Springfield, VA 22161 \\ ph: (800) 553-6847 \\ fax: (703) 605-6900 \\ email: orders@ntis.fedworld.gov \\ online ordering: http://www.ntis.gov/ordering.htm
}




\title{
Relative Hazard and Risk Measure Calculation Methodology
}

\author{
R.D. Stenner \\ W.B. Andrews \\ D.L. Strenge \\ T.L. Walton \\ M.S. ELder
}

September 2003

Prepared for the U.S. Department of Energy under Contract DE-AC06-76RL01830

Pacific Northwest National Laboratory

Richland, Washington 99352 


\section{Summary}

The new RHRM methodology and code is designed for use as a management-focused decision analysis tool to examine "accelerated cleanup" and alternative mitigation approaches, from a human health risk

basis. The original RHRM methodology, developed for the Center for Risk Excellence (CRE) by PNNL, was developed to provide graphics depicting the change in hazard and risk over time for the DOE complex-wide risk profiles being developed by the CRE. The original RHRM methodology has been upgraded considerably to focus on this broader application and use. The upgrades include 1) revised health measure (HM) parameter tables to better represent the potential impact to individuals by each transport route. 2) revised definition, use, and evaluation of the hazard control (HC) factors to better represent the physical environments being modeled. 3) improved methods of incorporation and representation of the waste processing and disposal actions as flow streams for evaluation by RHRM. 4) improved guidance on the selection of hazard likelihood values needed to estimate the risk measure. and 5) improved guidance on the selection of parameter values for evaluating the release potential for waste storage, handling, and treatment configurations (i.e., release-exposure scenarios). The tool has also been set in a basic web-based format and now has the capability of using the PNNL developed FRAMES model integration tool for more flexibility with input data and linking to a host of fate and transport and risk models.

The RHRM equations, as represented in methodology and code presented in this report, are primarily a collection of key factors normally used in risk assessment that are relevant to understanding the hazards and risks associated with projected mitigation, cleanup, and risk management activities. The RHRM code has broad application potential. For example, it can be used to compare one mitigation, cleanup, or risk management activity with another, instead of just comparing it to just the fixed baseline. If the appropriate source term data are available, it can be used in its non-ratio form to estimate absolute values of the associated controlling hazards and risks. These estimated values of controlling hazards and risks can then be examined to help understand which mitigation, cleanup, or risk management activities are addressing the higher hazard conditions and risk reduction potential at a site. Graphics can be generated from these absolute controlling hazard and risk values to graphically compare these high hazard and risk reduction potential conditions. If the RHRM code is used in this manner, care must be taken to specifically define and qualify (e.g., identify which factors were considered and which ones tended to drive the hazard and risk estimates) the resultant absolute controlling hazard and risk values. 


\section{Acknowledgements}

The original Relative Hazard and Risk Measure Calculation Methodology (PNNL-12008 Rev. 1) was developed in support of the Department of Energy (DOE) - Center for Risk Excellence (CRE). The authors would like to acknowledge the insight and forward thinking of Dr. Al Young, CRE Director, for encouraging and sponsoring the original effort to establish this management-level hazard and risk analysis capability and tool.

A special acknowledgement also goes to Virginia Kay of the Department of Energy - Savannah River Site (DOE/SRS) and the SRS Citizen Advisory Board (CAB) for their insight and guidance associated with the development of the original "risk measure" aspect of the capability and tool.

The revised and upgraded Relative Hazard and Risk Measure Calculation Methodology, discussed in this report, was developed under the Pacific Northwest National Laboratory (PNNL) Laboratory Directed Research and Development (LDRD) program.

The authors also wish to acknowledge and thank Bruce Napier (PNNL) for providing peer review and excellent technical suggestions for improving the document. 


\section{Contents}

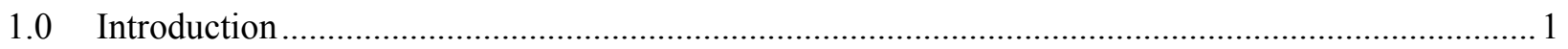

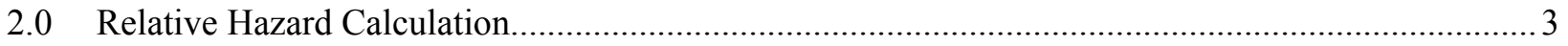

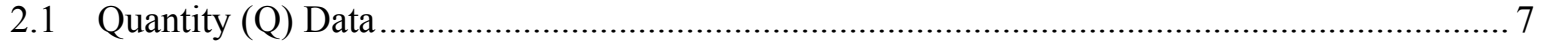

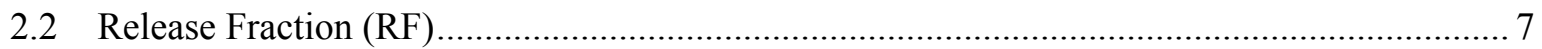

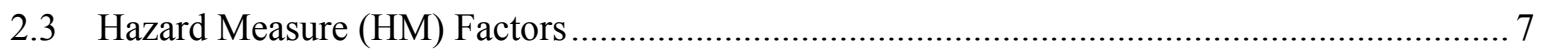

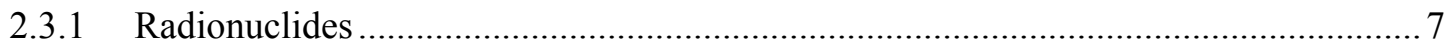

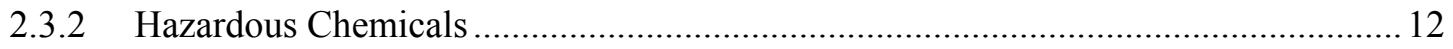

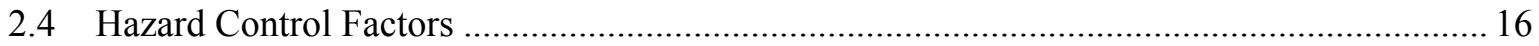

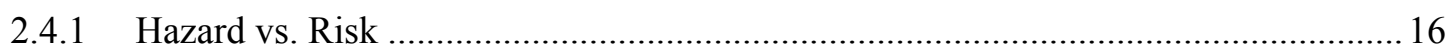

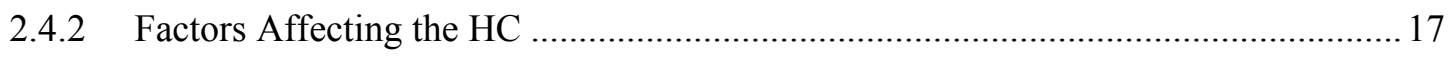

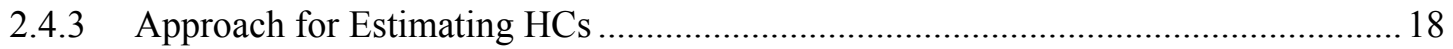

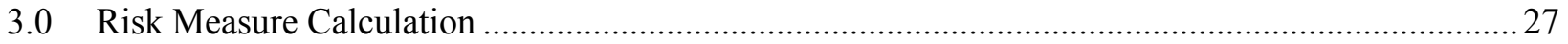

3.1 Hazard Likelihood Factor............................................................................................... 31

3.2 Reductions in Hazard Likelihood Factor.............................................................................. 34

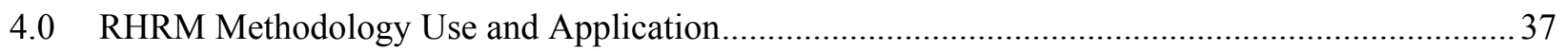

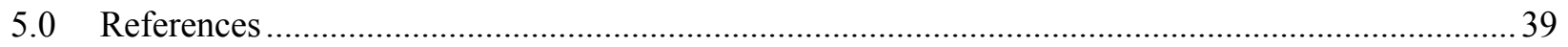




\section{Tables}

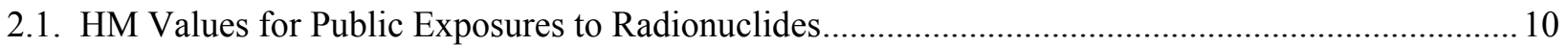

2.2. HM Values for Worker Exposures to Radionuclides......................................................................... 11

2.3. Partition Coefficients $\left(\mathrm{K}_{\mathrm{d}} \mathrm{s}\right)$ and Derived Groundwater Transfer

Coefficients Used in the Groundwater Exposer Pathway Radionuclide Categories.......................... 12

2.4. HM Values for Public Exposures to Hazardous Chemicals......................................................... 14

2.5. HM Values for Worker Exposures to Hazardous Chemicals........................................................ 15

2.6. Hazard Reduction Measures with Generic Hazard Control (HC) Factors ........................................20

2.7. Contaminant Categories .............................................................................................................. 21

2.8. Arid Site Guidance Table for Estimating Default HC Factors (Log Scale) ....................................22

2.9. Humid Site Guidance Table for Estimating Default HC Factors (Log Scale) .................................23

2.10. Arid Site Guidance Table for Estimating Default HC Factors (Log Scale) ...................................24

2.11. Humid Site Guidance Table for Estimating Default HC Factors (Log Scale) ................................25

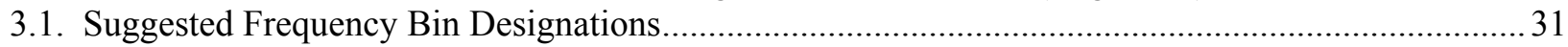

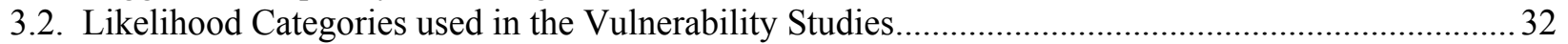

3.3. Likelihood Summary for Plutonium Vulnerability Study ........................................................... 32

3.4. Likelihood Summary for the Highly-Enriched Uranium Vulnerability Study ...................................34

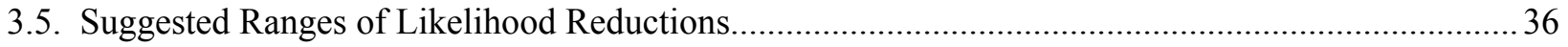




\subsection{Introduction}

In February 1997, the Department of Energy (DOE) Center for Risk Excellence (CRE) was created and charged as a technical, field-based partner to the Office of Science and Risk Policy (EM-52). One of the initial charges to the CRE was to assist DOE sites in the development of "site risk profiles." These profiles were to be relatively short summaries (periodically updated) that present a broad perspective on the major risk related challenges that face the respective site. The risk profiles were intended to serve as a management-level communication tool for interested internal and external parties to enhance the understanding of these risk-related challenges. The risk profiles focused on the presentation of the following information: 1) a brief overview of the site, 2) a brief discussion on the historical mission of the site, 3) a quote from the site manager indicating the site's commitment to risk management, 4) a listing of the site's top risk-related challenges, 5) a brief discussion and detailed table presenting the site's current risk picture, 6) a brief discussion and detailed table presenting the site's future risk reduction picture, and 7) graphic illustrations of the projected management of the relative hazards at the site. During fiscal year 1998, risk profiles that used the methodology discussed in this report were developed for the Richland Operations Office (DOE, 1998a), Nevada Operations Office (DOE, 1998b), Rocky Flats Field Office (DOE, 1998c), Savannah River Operations Office (DOE, 1998d), and Albuquerque Operations Office (DOE, 1998e).

The relative hazard $(\mathrm{RH})$ reduction graphic illustrations were included to provide the reader of the risk profiles with a management-level mental picture to associate with the qualitative information presented in the risk profile. Inclusion of the relative hazard profile graphics presented the CRE with the challenge of how to fold the management-level qualitative risk information into a system to produce quantitative results that would depict the relative change in hazard associated with each major environmental cleanup or risk management action so it could be tracked graphically. Thus, the initial RH equation and methodology was developed that rolled up the factors normally considered in hazard and risk assessments to produce a "management level" hazard assessment capability that tracked controlling parameters and scenarios and produced a profile of the hazards as they changed over time due to mitigation and cleanup actions. In the perspective of a routine risk assessment, the RH is a measure of the consequences associated with a probability of one for the controlling constituents and scenarios.

The risk measure aspect was added as the result of feedback and technical support provided by the Savannah River Site (SRS) Citizen Advisory Board (CAB). The CAB felt that it was not only important to track the change in hazard over time, but that it was equally important to track the maintenance of acceptable risk of the operation and facility over time while the hazard was being managed and ultimately reduced. The Risk Measure (RM) is related to the relative hazard by the frequency of a release event for the operation or activity. The RM is calculated in a manner similar to the relative hazard by using an additional hazard likelihood (HL) factor to the relative hazard equation. The hazard likelihood is represented as the expected frequency of the event that results in release of a contaminant to the environment.

Use of the RHRM methodology progressed from simply using it to produce the risk profiles to using it as a management-focused decision analysis tool to examine "accelerated cleanup" and alternative approaches from a human health risk basis. In using the methodology as a risk-based management decision analysis tool, it became clear that it needed to be made more user-friendly, web-based, and upgraded to provide more clarity in the selection and use of input parameters. Since the CRE has been eliminated, due to DOE restructuring, and use of the tool has shifted more in the support of DOE operations office-based programs and site contractors, a proposal was submitted to and awarded by the PNNL LDRD program for upgrading the existing RHRM methodology. The upgrades include 1) revised 
health measure (HM) parameter tables to better represent the potential impact to individuals by each transport route. 2) revised definition, use, and evaluation of the hazard control (HC) factors to better represent the physical environments being modeled. 3) improved methods of incorporation and representation of the waste processing and disposal actions as flow streams for evaluation by RHRM. 4) improved guidance on the selection of hazard likelihood values needed to estimate the risk measure. and 5) improved guidance on the selection of parameter values for evaluating the release potential for waste storage, handling, and treatment configurations (i.e., release-exposure scenarios). The tool has also been set in a web-based format and now has the capability of using the PNNL developed FRAMES model integration tool for more flexibility with input data and linking to a host of fate and transport and risk models.

The term "controlling constituent" is used often in this document. Controlling constituents are those radionuclides and hazardous chemicals in a particular waste type that tend to control the impact or hazardousness of the consequence(s) associated with the waste material. That is, they are the radionuclides and hazardous chemicals that tend to drive the health concern over the need to control the waste material. In the analysis methods discussed in this document, it is advantageous to limit the number of controlling constituents to as few as possible and still adequately represent the hazardousness of the waste material. In most risk assessments there are usually just one or two constituents that tend to drive the risk. It is these constituents that we are calling "controlling constituents." 


\subsection{Relative Hazard Calculation}

The original methodology evaluated the RH value on an annual basis. Material was considered "in process" or "in storage" for the entire year. Material moving from process to storage during the year was considered "in process" for the entire year, then changed to "in storage" at the start of the next year. Experience in using the RHRM methodology has shown that this is often not as accurately representative of actual disposition planning as desired. The original RH methodology was revised to allow RH (and $\mathrm{RM}$ ) to be evaluated for a material processed and stored (in a before-and-after state) during the same year.

The evaluation of relative hazard from a material now includes consideration of the time during which the material is in each state during a year. Also, multiple material forms are now considered in the evaluation of annual RH values. The following revisions were made to the RH methodology to include consideration of the total time during a year that the material is in each state (i.e., stored or in processing). For practical purposes, the maximum number of states is limited.

The original equation for evaluating $\mathrm{RH}$ at a specific time (year end) was as follows:

$$
R H=\frac{\sum_{c c=1}^{n} Q_{c c t} R F_{c c c t} H M_{c c t} H C_{c c t}}{\sum_{c c=1}^{n} Q_{c c t 0} R F_{c c c t 0} H M_{c c t 0} H C_{c c t 0}}
$$

where $\quad \mathrm{Q}_{\mathrm{cct}}=$ quantity of the controlling constituents (radionuclides, in curies and hazardous chemicals, in kilograms) at time $\mathrm{t}$ (i.e., time when specified risk management action is completed)

$\mathrm{Q}_{\mathrm{cct} 0}=$ quantity of the controlling constituents (radionuclides, in curies and hazardous chemicals, in kilograms) at time t0 (i.e., the original baseline or starting time)

$\mathrm{RF}_{\text {cct }}=$ fraction of controlling constituent quantity that is releasable to the controlling pathway at time $\mathrm{t}$

$\mathrm{RF}_{\text {cct } 0}=$ fraction of the controlling constituent quantity that is releasable to the controlling pathway at time t0

$\mathrm{HM}_{\mathrm{cct}}=$ hazard measure factor for controlling constituent and controlling pathway at time $\mathrm{t}$ (hazard measure factors from look-up tables)

$\mathrm{HM}_{\mathrm{cct} 0}=$ hazard measure factor for controlling constituent and controlling pathway at time t0 (hazard measure factors from look-up tables)

$\mathrm{HC}_{\mathrm{cct}}=$ hazard control factor for risk management control action specific at time $\mathrm{t}$ (hazard control factors may be estimated from site risk data or approximated using supplied look-up tables) 


$$
\begin{aligned}
\mathrm{HC}_{\text {cct0 }}= & \text { hazard control factor for risk management control action specific at time t0 } \\
& \text { (hazard control factors may be estimated from site risk data or approximated } \\
& \text { using supplied look-up tables) } \\
\mathrm{n}= & \text { number of controlling constituents. }
\end{aligned}
$$

The original equation was written with time as a general parameter. This necessitated implementation to be limited to 1-year time periods: results could only be presented on an annual basis, which was fine for the original hazard and risk profile purposes. However, expanded management applications of the methodology necessitated accounting for specific material-state time periods. Thus, the RH (and RM equation, see Section 3) equation was modified to explicitly represent each material state involved in each year of the analysis. An additional parameter was added to the numerator of the equation to account for the fraction of a year that the material is in each state. If the assumption is made in an application that the initial condition involves only storage of material in the initial state, for example, then the time factors will simply be unity.

The original equation was based on the hazardous material being represented as an analyte (e.g., $\left.{ }^{239} \mathrm{Pu}\right)$. The revised equation is based on material states with the analyte as a sub-component of the material. The revised RH (and RM) equation includes the following parameterizations:

Time: each evaluation is performed for a one year period, with the results applied at the end of the year.

Material state: all material states involved in the current year are analyzed. The fraction of the year that a material is in each state must be defined.

Analyte: each material is composed of one or more hazardous analytes. These analytes determine the nature of the hazard associated with the material. The hazard measure (HM) values are based on the analyte properties.

The revised RH equation includes the summation over material types as shown in the equation below. In the revised equation, the original subscript for contaminant of concern (cc) has been simplified to one letter (c) and a new index for material " $m$ " has been added.

$$
R H=\frac{\sum_{c c=1}^{n} \sum_{m=1}^{M} F_{m t} Q_{c m t} R F_{c m t} H M_{c t} H C_{c m t}}{\sum_{c=1}^{n} \sum_{m=1}^{M} F_{m 0} Q_{c m t 0} R F_{c m t 0} H M_{c t 0} H C_{c m t 0}}
$$

where $\quad \mathrm{Q}_{\mathrm{cmt}}=$ quantity of the controlling constituents (radionuclides, in curies and hazardous chemicals, in kilograms) for material state $\mathrm{m}$, at time $\mathrm{t}$ (i.e., time when specified risk management action is completed)

$\mathrm{Q}_{\mathrm{cmt} 0}=$ quantity of the controlling constituents (radionuclides, in curies and hazardous chemicals, in kilograms) in material state $\mathrm{m}$, at time t0 (i.e., the original baseline or starting time)

$\mathrm{F}_{\mathrm{mt}}=$ fraction of time that the material is in state $\mathrm{m}$ during time $\mathrm{t}$

$\mathrm{F}_{\mathrm{m} 0}=$ fraction of time that the material is in state $\mathrm{m}$ at the initial time 


$$
\begin{aligned}
& \mathrm{RF}_{\mathrm{cmt}}=\text { fraction of controlling constituent quantity in material state } \mathrm{m} \text {, that is } \\
& \text { releasable to the controlling pathway at time } t \\
& \mathrm{RF}_{\mathrm{cmt} 0}=\text { fraction of the controlling constituent quantity in material state } \mathrm{m} \text {, that is } \\
& \text { releasable to the controlling pathway at time t0 } \\
& \mathrm{HM}_{\mathrm{ct}}=\text { hazard measure factor for controlling constituent and controlling pathway at } \\
& \text { time } t \text { (hazard measure factors from look-up tables) } \\
& \mathrm{HM}_{\mathrm{ct} 0}=\text { hazard measure factor for controlling constituent and controlling pathway at } \\
& \text { time t0 (hazard measure factors from look-up tables) } \\
& \mathrm{HC}_{\mathrm{cmt}}=\text { hazard control factor for risk management control action specific at time } \mathrm{t} \text { for } \\
& \text { material state } \mathrm{m} \text { (hazard control factors may be estimated from site risk data or } \\
& \text { approximated using supplied look-up tables) } \\
& \mathrm{HC}_{\mathrm{cmt} 0}=\text { hazard control factor for risk management control action specific at time } \mathrm{t} 0 \text { for } \\
& \text { material state } \mathrm{m} \text { (hazard control factors may be estimated from site risk data or } \\
& \text { approximated using supplied look-up tables) } \\
& \mathrm{M}=\text { number of material states } \\
& \mathrm{n}=\text { number of controlling constituents. }
\end{aligned}
$$

In the revised equation, the new summation is over material states. For the base case (time zero), only those states that are initially present (e.g. storage states) are included in the analysis because the time factors, $F_{m 0}$, for other states are zero. The initial time factors for the included states, $F_{\mathrm{m} 0}$, are assigned a value of 1.0. Another change has been to add dependence on material state to the HC parameters because the location of the material can influence the $\mathrm{HC}$ factor.

\section{Implementation changes}

Implementation of the original RHRM equations involved reading PROCESS keywords defining actions taken that change the state of materials. The initial and final states were defined, and then the fraction of the initial state that changed was given, followed by the duration of the period over which the change occurs. The assumption was made that the change occurred uniformly over the time period. The times were in multiples of 1 year. This representation was updated to account for processing that occurs within one year, so that the final state (e.g., a second storage state) and all intermediate processing states are included in the analysis during the current year.

The following is an example of the kinds of one year of disposition activity that involves processing.

Initial state: Storage in a vault, state 1.

Processes: $\quad$ Removal from vault and transfer to processing cell. Processing of material to stable state in processing cell, state 2. Transfer of material from processing cell to final storage location in stable state.

Final state: $\quad$ Storage of stable state in new storage configuration.

The analysis must include the fraction of the year that the material is in each storage state and the fraction of the year that the material is out of storage for processing. The above example shows three material 
states. The numerator of the RH equation for this example can be written as follows for analyte $\mathrm{c}$ and time period t:

$\mathrm{RH}$ (numerator) $=\left(\mathrm{Q}_{\mathrm{c} 1 \mathrm{t}} \mathrm{F}_{1 \mathrm{t}} \mathrm{RF}_{\mathrm{c} 1 \mathrm{t}} \mathrm{HC}_{\mathrm{c} 1 \mathrm{t}}+\mathrm{Q}_{\mathrm{c} 2 \mathrm{t}} \mathrm{F}_{2 \mathrm{t}} \mathrm{RF}_{\mathrm{c} 2 \mathrm{t}} \mathrm{HC}_{\mathrm{c} 2 \mathrm{t}}+\mathrm{Q}_{\mathrm{c} 3 \mathrm{t}} \mathrm{F}_{3 \mathrm{t}} \mathrm{RF}_{\mathrm{c} 3 \mathrm{t}} \mathrm{HC}_{\mathrm{c} 3 \mathrm{t}}\right) \mathrm{HM}_{\mathrm{ct}}$

$\mathrm{F}_{1 \mathrm{t}}+\mathrm{F}_{2 \mathrm{t}}+\mathrm{F}_{3 \mathrm{t}} \leq 1.0$

It should be noted that the sum of time fractions could be less than one if material is transported offsite and the analysis is only to include consideration of onsite material.

The RH associated with the processing operation (material state 2 in the above example) would be assigned to the entire time period out of storage. This should be a reasonable assumption because materials are usually kept in storage when not being processed.

The RHRM FORTRAN code was revised to implement the revised equation to better represent the processing of material as a function of time as it goes through the various material states.

Initial material states are required for evaluation of the denominator in the RH equation. No processing is involved in the initial material states. In the RHRM code, processing is represented using the PROCESS keyword records read from the processing keyword file. Each PROCESS keyword record defines an initial and final state, the time period of processing, and the fraction of the initial material that is processed during the time period. The final state represents the material state while being processed. A subsequent PROECSS keyword record is required to move the material from the processing state to the next material storage state. This representation has resulted in the need to do significant prior analyses to determine the correct representation and processing fractions for each PROCESS keyword record. The goal of the current revision is to develop a simpler method to represent the changes in material state with time so prior analyses are not necessary.

In the RHRM code, the SCOPE keyword record is used to define all material states to be included in the analysis and the amount of material initially present in the material states. The amount on the SCOPE record is the total $\mathrm{kg}$ of material. The concentration of each analyte in the material is defined on MATERIAL keyword records. For example, the MATERIAL keyword record will provide the $\mathrm{Ci} / \mathrm{kg}$ of each radionuclide in the material.

\section{Relation of RHRM code parameters to the RH equation}

The quantity of an analyte in a material state at time $t\left(\mathrm{Q}_{\mathrm{cmt}}\right)$ is represented as the product of the amount of material present in the material state in time period $\mathrm{t}(1$ calendar year) and the concentration of the analyte in the material, with correction for decay as necessary. The relative hazard considers this quantity of material and the time $\left(\mathrm{F}_{\mathrm{mt}}\right)$ it is in each state during the year. The product of $\mathrm{Q}_{\mathrm{cmt}}$ and $\mathrm{F}_{\mathrm{mt}}$ is the basis for determining the relative hazard during period $\mathrm{t}$ for material $\mathrm{m}$ and analyte $\mathrm{c}$, as indicated in the above example.

The amount of material present in the material state is not explicitly represented in the RH equation, but must be determined in the RHRM code implementation of the equation. This is the basis for the change in $\mathrm{RH}$ with time. The initial material present (time zero) is provided in the SCOPE keyword records. 


\section{Revised Processing Algorithm}

A revised processing algorithm was developed for the RHRM code to better represent the time change of material in each material state. This was necessary to implement the change in the RH equation described above where the time fraction parameter, $\mathrm{F}_{\mathrm{mt}}$, has been added to the analysis.

\subsection{Quantity (Q) Data}

The best available site-specific quantity data should be used when calculating the RH ratios. In order for the $\mathrm{RH}$ ratios to be comparable across the different waste types, the quantity data should be specific to each controlling constituent and should be provided in units of curies for radionuclides or kilograms for hazardous chemicals. If exact amounts of each controlling constituent are not available, rough estimates of the fraction of each controlling constituent contained in the total waste quantity can be made. These fractions can then be used to adjust the total waste quantity to estimate the quantity of each respective controlling constituent. If controlling constituent quantity data in curies (radionuclides) or kilograms (hazardous chemicals) are just not available and it is not possible to estimate the fractions of each controlling constituent in the total waste quantity, the total waste quantity of each waste type can be used as a rough surrogate, as long as the units of this quantity remain the same through out the analysis of the respective waste type. However, this will generally make the RH result non-comparable across waste types and may not provide very accurate RH ratios for risk management actions that involve treatment of the controlling constituent(s).

\subsection{Release Fraction (RF)}

In some cases, the total quantity of a controlling constituent is not all releasable to the controlling exposure pathway (i.e., dominant exposure pathway) of concern. In these cases, a release fraction (i.e., the fraction of the total quantity of the controlling constituent that is releasable to the controlling pathway) should be provided for use in the RH equation to adjust the quantity, so that only the fraction of the controlling constituent quantity that can actually be released to the exposure pathway is considered. If all of the controlling constituent quantities are available for release to the controlling exposure pathway, which is true for many waste type situations, simply assign the RF factor a " $1 . "$

\subsection{Hazard Measure (HM) Factors}

The HM considers the inherent toxicity or carcinogenic potential of the controlling contaminant(s) identified, as well as its potential to expose members of the public through various exposure pathways. Because constituent HMs are determined a priori, HM, along with Q, is probably one of the least subjective of the RH equation factors. HM factor look-up tables are provided.

\subsubsection{Radionuclides}

The HM for radionuclides can be considered similar to an exposure pathway-specific dose factor, although the modeling is not detailed enough to provide an absolute dose estimate. The basis for determining the HM for radionuclides was originally developed for the Modified Hazard Ranking System (MHRS). The MHRS was developed to work within the framework of the EPA's Hazard Ranking System (HRS) (FR 31219-31243), but also to provide a more appropriate treatment of radionuclides in ranking mixed waste sites for the National Priority List (NPL) under the Comprehensive Environmental 
Response, Compensation, and Liability Act (CERCLA). Radionuclides are evaluated under three potential exposure pathways: air, surface water, and groundwater.

The MHRS was designed for generic application anywhere the EPA HRS could be used, included a limited suite of radionuclides, and used the ICRP Publication 2 (ICRP 1959) critical organ concept in assigning a potential hazard ranking to radionuclides. While the general concept used in the MHRS was retained, several enhancements were made to the HM factors presented for use in the RH calculations. Additional radionuclides are included, although, like the MHRS-based HM factors, the RH-based HM factors are generally limited to those radionuclides with a half-life of 1 year or greater, unless they were specifically noted as being potentially important in one of the specific waste materials considered. The dose calculation methodology was updated to ICRP Publication 30 (ICRP 1979), using the GENII computer codes (Napier et al. 1988a; 1988b; 1988c) to perform updated calculations for the five exposure pathways. Radionuclide HMs are now based upon effective dose equivalent (EDE) rather than critical organ dose. The methodology used to produce the RH-based HM values used default inputs of the GENII code, and, for the groundwater exposure pathway, used groundwater transfer partition coefficients $\left(\mathrm{K}_{\mathrm{d}}\right)$ from Serne and Wood (1990).

Like the MHRS-based factors, the RH-based HM factors are based upon near-field scenarios. In a nearfield scenario, interest is focused on the doses an individual could receive at a particular location as a result of initial contamination or external sources (i.e., buried solid waste, contaminated soil, contaminated water, or contamination in air). This differs from a far-field scenario, defined as determining impacts of a particular release of radioactive or hazardous material into a wide environment, such as the dose from releases from a stack to individuals or populations downwind. Near-field assumptions were used, since the only basic difference between near-field and far-field scenarios is dilution. In an RH analysis, the affect of dilution distance is accounted for in the Hazard Control (HC) parameter associated with relocation of material further from a receptor.

Descriptions of the exposure assumptions and radionuclide categories for each of the three exposure pathways are provided in the sections below, along with the respective HM factor look-up tables. In each exposure pathway table, radionuclides are categorized by the approximate dose received per unit concentration.

\section{Air Exposure Pathway}

This is a chronic exposure pathway that primarily poses long-term, large-scale risks to the public. Assumptions are that the exposed individual 1) lives continuously in contaminated air (chronic inhalation), 2) is continuously exposed to external radiation from radionuclides deposited on the ground surface, and 3) is continuously immersed in the airborne radioactive plume. The values of the HM factor for the air exposure pathway are given in Table 2.1 for selected radionuclide exposures to the public and Table 2.2 for selected radionuclide exposures to workers.

\section{Surface Water Exposure Pathway}

This is a chronic exposure pathway that primarily poses long-term risks to public users of local surface water sources. Assumptions are that the exposed individual 1) eats food irrigated with contaminated surface water at an irrigation rate of $150 \mathrm{~L} / \mathrm{m}^{2} / \mathrm{mo}$ for $6 \mathrm{mo} / \mathrm{yr}, 2$ ) eats fish from the contaminated water, 3 ) is exposed to external radiation from contaminated sediments along the bank, and 4) gets drinking water from the contaminated surface water. Resuspension of external radiation from radionuclides deposited on the soil from irrigation are not considered. The values of the HM factor for the surface-water 
exposure pathway are given in Table 2.1 for selected radionuclide exposures to the public and Table 2.2 for selected radionuclide exposures to workers.

\section{Groundwater Exposure Pathway}

This is a chronic exposure pathway that primarily poses long-term risks to public users of the local surface water sources. Groundwater is assumed to connect with surface water through infiltration, and exposure is via the surface water exposure pathway. No direct groundwater exposure via groundwater wells is assumed. Assumptions are that the exposed individual 1) eats food irrigated with surface water contaminated via connection with groundwater at an irrigation rate of $150 \mathrm{~L} / \mathrm{m}^{2} / \mathrm{mo}$ for $6 \mathrm{mo} / \mathrm{yr}, 2$ ) eats fish from the contaminated water, 3 ) is exposed to external radiation from contaminated sediments along the bank, and 4) gets drinking water from the contaminated surface water. Resuspension of external radiation from radionuclides deposited on the soil from irrigation is not considered.

The groundwater-to-surface-water exposure pathway radionuclide categories were adjusted for the tendency of radionuclides to adsorb to soil particles (partition coefficient, Kd) during groundwater transport. Partition coefficients were obtained (Serne and Wood 1990) and converted to groundwater transfer coefficients from 1 to 100 (Hawley and Napier 1985; Hawley et al. 1986) to be consistent with the multiplicative RH strategy. The Kd values used for each radionuclide and the derived groundwater transfer coefficients are shown in Table 2.3. The HM factor for groundwater does not consider the time it takes the radionuclide to move through the vadose zone to the saturated zone and to a point where it could fit the near-field scenario. The values of the HM factor for the groundwater exposure pathway are given in Table 2.1 for selected radionuclide exposures to the public and Table 2.2 for selected radionuclide exposures to workers. 
Table 2.1. HM Values for Public Exposures to Radionuclides

\begin{tabular}{|c|c|c|c|c|c|}
\hline & & $\mathrm{Bq} / \mathrm{m} 3$ & $\mathrm{pCi} / \mathrm{m} 3$ & $\mathrm{pCi} / \mathrm{L}$ & $\mathrm{pCi} / \mathrm{L}$ \\
\hline Radionuclide & & \multicolumn{2}{|c|}{ Air Incidence } & GW Incidence & SW Incidence \\
\hline Am241 & & 5.279E-02 & 1.96E-03 & $4.31 \mathrm{E}-06$ & 6.39E-06 \\
\hline Be10 & & $4.218 \mathrm{E}-05$ & $1.56 \mathrm{E}-06$ & $2.17 \mathrm{E}-09$ & $2.48 \mathrm{E}-09$ \\
\hline C14 & & $3.198 \mathrm{E}-06$ & $1.18 \mathrm{E}-07$ & $1.08 \mathrm{E}-09$ & 1.48E-08 \\
\hline Cd109 & & $1.452 \mathrm{E}-05$ & 5.38E-07 & 5.98E-09 & 1.07E-08 \\
\hline Cf252 & & $1.866 \mathrm{E}-02$ & $6.91 \mathrm{E}-04$ & $1.22 \mathrm{E}-06$ & 1.47E-06 \\
\hline $\mathrm{Cl} 36$ & & $1.247 \mathrm{E}-05$ & 4.62E-07 & 2.04E-09 & 1.15E-08 \\
\hline Cm242 & & 2.055E-03 & 7.61E-05 & $1.22 \mathrm{E}-07$ & 1.81E-07 \\
\hline $\mathrm{Cm} 243$ & & $3.654 \mathrm{E}-02$ & $1.35 \mathrm{E}-03$ & $2.94 \mathrm{E}-06$ & 4.36E-06 \\
\hline $\mathrm{Cm} 244$ & & $2.951 \mathrm{E}-02$ & $1.09 \mathrm{E}-03$ & $2.35 \mathrm{E}-06$ & $3.49 \mathrm{E}-06$ \\
\hline $\mathrm{Cm} 245$ & & $5.410 \mathrm{E}-02$ & $2.00 \mathrm{E}-03$ & $4.43 \mathrm{E}-06$ & $6.57 \mathrm{E}-06$ \\
\hline Co60 & & $9.485 \mathrm{E}-05$ & $3.51 \mathrm{E}-06$ & $1.34 \mathrm{E}-08$ & $2.90 \mathrm{E}-08$ \\
\hline Cs134 & & 5.179E-05 & $1.92 \mathrm{E}-06$ & $3.66 \mathrm{E}-08$ & $2.57 \mathrm{E}-07$ \\
\hline Cs135 & & $1.083 \mathrm{E}-06$ & $4.01 \mathrm{E}-08$ & $3.55 \mathrm{E}-09$ & $2.50 \mathrm{E}-08$ \\
\hline Cs137 & & $2.277 \mathrm{E}-05$ & $8.43 E-07$ & $2.51 \mathrm{E}-08$ & 1.77E-07 \\
\hline Eu152 & & 5.902E-05 & $2.19 \mathrm{E}-06$ & 4.11E-09 & 5.26E-09 \\
\hline Eu154 & & 6.872E-05 & $2.55 \mathrm{E}-06$ & 5.87E-09 & 7.41E-09 \\
\hline Eu155 & & $6.652 \mathrm{E}-06$ & $2.46 \mathrm{E}-07$ & $9.13 \mathrm{E}-10$ & 1.12E-09 \\
\hline Fe55 & & $3.411 \mathrm{E}-07$ & $1.26 \mathrm{E}-08$ & 3.03E-10 & 2.05E-09 \\
\hline $\mathrm{H} 3$ & & 1.657E-08 & $6.14 \mathrm{E}-10$ & $2.98 \mathrm{E}-11$ & $3.16 \mathrm{E}-14$ \\
\hline 1129 & & 4.357E-05 & 1.61E-06 & $1.30 \mathrm{E}-07$ & 3.89E-07 \\
\hline Mn54 & & 1.985E-05 & 7.35E-07 & 1.23E-09 & 3.14E-09 \\
\hline Mo93 & & $3.642 \mathrm{E}-06$ & 1.35E-07 & $1.30 \mathrm{E}-09$ & 1.59E-09 \\
\hline $\mathrm{Na22}$ & & $6.180 \mathrm{E}-05$ & $2.29 \mathrm{E}-06$ & $7.12 \mathrm{E}-09$ & 1.66E-08 \\
\hline $\mathrm{Nb94}$ & & 9.705E-05 & 3.59E-06 & $8.17 \mathrm{E}-09$ & $1.32 \mathrm{E}-08$ \\
\hline $\mathrm{Ni59}$ & & $3.280 \mathrm{E}-07$ & $1.21 \mathrm{E}-08$ & $9.62 \mathrm{E}-11$ & $1.43 \mathrm{E}-10$ \\
\hline Ni63 & & 7.677E-07 & $2.84 \mathrm{E}-08$ & $2.65 \mathrm{E}-10$ & 3.93E-10 \\
\hline Np237 & & $6.424 \mathrm{E}-02$ & $2.38 \mathrm{E}-03$ & $5.24 \mathrm{E}-06$ & $7.78 \mathrm{E}-06$ \\
\hline Np239 & & 4.063E-07 & $1.50 \mathrm{E}-08$ & $1.24 \mathrm{E}-09$ & $1.32 \mathrm{E}-09$ \\
\hline $\mathrm{Pb} 212$ & Progeny & $2.003 \mathrm{E}-05$ & $7.42 \mathrm{E}-07$ & $9.20 \mathrm{E}-09$ & $9.23 \mathrm{E}-12$ \\
\hline Pm147 & & 4.684E-06 & $1.73 \mathrm{E}-07$ & $6.08 \mathrm{E}-10$ & 7.34E-10 \\
\hline Pu238 & & 4.667E-02 & 1.73E-03 & 3.75E-06 & 5.57E-06 \\
\hline Pu239 & & 5.109E-02 & 1.89E-03 & 4.19E-06 & $6.21 E-06$ \\
\hline Pu240 & & $5.109 \mathrm{E}-02$ & 1.89E-03 & $4.19 \mathrm{E}-06$ & $6.21 \mathrm{E}-06$ \\
\hline Pu241 & & 9.816E-04 & 3.64E-05 & 8.06E-08 & $1.20 \mathrm{E}-07$ \\
\hline Ra224 & Progeny & $3.992 \mathrm{E}-04$ & $1.48 \mathrm{E}-05$ & $1.66 \mathrm{E}-07$ & $1.75 \mathrm{E}-10$ \\
\hline Ra226 & & $1.054 \mathrm{E}-03$ & 3.90E-05 & $5.86 \mathrm{E}-07$ & 8.10E-07 \\
\hline Ra228 & Progeny & 6.646E-04 & 2.46E-05 & $6.38 \mathrm{E}-07$ & 8.80E-10 \\
\hline Sb125 & & 1.325E-05 & 4.91E-07 & 1.25E-09 & 2.32E-09 \\
\hline Se79 & & 1.641E-06 & $6.08 \mathrm{E}-08$ & $4.22 \mathrm{E}-09$ & 7.42E-09 \\
\hline Sm151 & & $3.578 \mathrm{E}-06$ & $1.33 \mathrm{E}-07$ & $3.52 \mathrm{E}-10$ & $4.26 \mathrm{E}-10$ \\
\hline Sr90 & & $1.619 \mathrm{E}-04$ & $6.00 \mathrm{E}-06$ & $6.31 \mathrm{E}-08$ & $8.79 \mathrm{E}-08$ \\
\hline Tc99 & & $2.549 \mathrm{E}-06$ & 9.44E-08 & $6.92 \mathrm{E}-10$ & $2.08 \mathrm{E}-09$ \\
\hline Th228 & Progeny & $4.058 \mathrm{E}-02$ & $1.50 \mathrm{E}-03$ & $1.49 \mathrm{E}-06$ & $1.85 \mathrm{E}-09$ \\
\hline Th232 & & 1.945E-01 & $7.20 \mathrm{E}-03$ & $1.14 \mathrm{E}-05$ & $1.41 \mathrm{E}-05$ \\
\hline $\mathrm{U} 233$ & & 1.603E-02 & 5.94E-04 & 1.33E-07 & $1.74 \mathrm{E}-07$ \\
\hline $\mathrm{U} 234$ & & 1.563E-02 & 5.79E-04 & 1.29E-07 & 1.70E-07 \\
\hline U235 & & 1.463E-02 & $5.42 \mathrm{E}-04$ & $1.21 \mathrm{E}-07$ & $1.60 \mathrm{E}-07$ \\
\hline U238 & & $1.403 \mathrm{E}-02$ & $5.20 \mathrm{E}-04$ & 1.17E-07 & $1.54 \mathrm{E}-07$ \\
\hline Minimum & & & $6.14 \mathrm{E}-10$ & $2.98 \mathrm{E}-11$ & $3.16 \mathrm{E}-14$ \\
\hline Maximum & & & $7.20 \mathrm{E}-03$ & $1.14 \mathrm{E}-05$ & $1.41 \mathrm{E}-05$ \\
\hline
\end{tabular}


Table 2.2. HM Values for Worker Exposures to Radionuclides

\begin{tabular}{|c|c|c|c|c|c|}
\hline & & $\mathrm{Bq} / \mathrm{m} 3$ & $\mathrm{pCi} / \mathrm{m} 3$ & $\mathrm{pCi} / \mathrm{L}$ & $\mathrm{pCi} / \mathrm{L}$ \\
\hline Radionuclide & & \multicolumn{2}{|c|}{ Air Incidence } & GW Incidence & SW Incidence \\
\hline Am241 & & $2.631 \mathrm{E}-02$ & $9.74 \mathrm{E}-04$ & $2.16 \mathrm{E}-06$ & $2.18 \mathrm{E}-06$ \\
\hline Be10 & & $2.100 \mathrm{E}-05$ & $7.78 \mathrm{E}-07$ & 1.08E-09 & 1.08E-09 \\
\hline C14 & & 1.240E-07 & 4.59E-09 & $4.61 \mathrm{E}-10$ & $4.61 \mathrm{E}-10$ \\
\hline Cd109 & & $6.750 \mathrm{E}-06$ & $2.50 \mathrm{E}-07$ & $2.97 \mathrm{E}-09$ & 2.98E-09 \\
\hline Cf252 & & $9.290 \mathrm{E}-03$ & $3.44 \mathrm{E}-04$ & $6.03 \mathrm{E}-07$ & $6.07 \mathrm{E}-07$ \\
\hline $\mathrm{Cl} 36$ & & 1.300E-07 & $4.81 \mathrm{E}-09$ & $6.68 \mathrm{E}-10$ & $6.68 \mathrm{E}-10$ \\
\hline $\mathrm{Cm} 242$ & & 1.020E-03 & $3.78 \mathrm{E}-05$ & $6.07 \mathrm{E}-08$ & $6.10 \mathrm{E}-08$ \\
\hline $\mathrm{Cm} 243$ & & $1.820 \mathrm{E}-02$ & $6.74 \mathrm{E}-04$ & $1.47 \mathrm{E}-06$ & $1.48 \mathrm{E}-06$ \\
\hline $\mathrm{Cm} 244$ & & 1.470E-02 & 5.44E-04 & $1.18 \mathrm{E}-06$ & 1.19E-06 \\
\hline $\mathrm{Cm} 245$ & & 2.690E-02 & 9.96E-04 & $2.21 \mathrm{E}-06$ & $2.23 \mathrm{E}-06$ \\
\hline Co60 & & 1.304E-05 & 4.83E-07 & 5.93E-09 & $6.22 \mathrm{E}-09$ \\
\hline Cs134 & & 2.764E-06 & 1.02E-07 & 1.61E-08 & 1.63E-08 \\
\hline Cs135 & & 2.690E-07 & 9.96E-09 & $1.56 \mathrm{E}-09$ & 1.56E-09 \\
\hline Cs137 & & $1.898 \mathrm{E}-06$ & $7.03 E-08$ & $1.10 \mathrm{E}-08$ & 1.10E-08 \\
\hline Eu152 & & $1.312 \mathrm{E}-05$ & $4.86 \mathrm{E}-07$ & $2.01 \mathrm{E}-09$ & $2.16 \mathrm{E}-09$ \\
\hline Eu154 & & 1.692E-05 & $6.27 \mathrm{E}-07$ & $2.87 \mathrm{E}-09$ & $3.02 \mathrm{E}-09$ \\
\hline Eu155 & & $2.451 \mathrm{E}-06$ & $9.08 \mathrm{E}-08$ & $4.47 \mathrm{E}-10$ & $4.55 \mathrm{E}-10$ \\
\hline Fe55 & & 1.590E-07 & 5.89E-09 & $1.36 \mathrm{E}-10$ & $1.36 \mathrm{E}-10$ \\
\hline $\mathrm{H} 3$ & & 3.730E-09 & $1.38 \mathrm{E}-10$ & 1.39E-11 & 1.39E-11 \\
\hline I129 & & 1.030E-05 & 3.81E-07 & $6.08 \mathrm{E}-08$ & $6.08 \mathrm{E}-08$ \\
\hline Mn54 & & 4.099E-07 & $1.52 \mathrm{E}-08$ & $6.13 \mathrm{E}-10$ & $6.97 \mathrm{E}-10$ \\
\hline Mo93 & & $1.680 \mathrm{E}-06$ & $6.22 \mathrm{E}-08$ & $6.26 \mathrm{E}-10$ & $6.27 \mathrm{E}-10$ \\
\hline $\mathrm{Na22}$ & & 4.872E-07 & $1.80 \mathrm{E}-08$ & $2.54 \mathrm{E}-09$ & $2.79 \mathrm{E}-09$ \\
\hline $\mathrm{Nb94}$ & & $2.452 \mathrm{E}-05$ & $9.08 \mathrm{E}-07$ & $1.60 \mathrm{E}-09$ & 1.79E-09 \\
\hline Ni59 & & $1.600 \mathrm{E}-07$ & 5.93E-09 & $4.63 \mathrm{E}-11$ & $4.64 \mathrm{E}-11$ \\
\hline Ni63 & & 3.720E-07 & $1.38 \mathrm{E}-08$ & $1.27 \mathrm{E}-10$ & $1.27 \mathrm{E}-10$ \\
\hline Np237 & & $3.200 \mathrm{E}-02$ & $1.19 \mathrm{E}-03$ & $2.63 \mathrm{E}-06$ & $2.65 \mathrm{E}-06$ \\
\hline Np239 & & 1.514E-07 & 5.61E-09 & $6.24 \mathrm{E}-10$ & $6.24 \mathrm{E}-10$ \\
\hline $\mathrm{Pb} 212$ & Progeny & 1.000E-05 & 3.70E-07 & 4.58E-09 & 4.58E-09 \\
\hline Pm147 & & $2.320 \mathrm{E}-06$ & $8.59 \mathrm{E}-08$ & $2.97 \mathrm{E}-10$ & $2.98 \mathrm{E}-10$ \\
\hline Pu238 & & $2.320 \mathrm{E}-02$ & $8.59 \mathrm{E}-04$ & $1.88 \mathrm{E}-06$ & $1.89 \mathrm{E}-06$ \\
\hline Pu239 & & $2.540 \mathrm{E}-02$ & $9.41 \mathrm{E}-04$ & $2.10 \mathrm{E}-06$ & $2.11 \mathrm{E}-06$ \\
\hline Pu240 & & $2.540 \mathrm{E}-02$ & 9.41E-04 & $2.10 \mathrm{E}-06$ & $2.11 \mathrm{E}-06$ \\
\hline Pu241 & & $4.880 \mathrm{E}-04$ & $1.81 \mathrm{E}-05$ & $4.04 \mathrm{E}-08$ & 4.07E-08 \\
\hline Ra224 & Progeny & 1.980E-04 & 7.33E-06 & $8.29 E-08$ & $8.30 \mathrm{E}-08$ \\
\hline Ra226 & & $5.080 \mathrm{E}-04$ & $1.88 \mathrm{E}-05$ & 2.93E-07 & 2.93E-07 \\
\hline Ra228 & Progeny & 3.010E-04 & 1.11E-05 & $3.18 \mathrm{E}-07$ & 3.19E-07 \\
\hline Sb125 & & 7.284E-07 & $2.70 \mathrm{E}-08$ & $6.19 \mathrm{E}-10$ & $6.70 \mathrm{E}-10$ \\
\hline Se79 & & $5.820 \mathrm{E}-07$ & $2.16 \mathrm{E}-08$ & 1.91E-09 & 1.91E-09 \\
\hline Sm151 & & $1.780 \mathrm{E}-06$ & $6.59 \mathrm{E}-08$ & $1.74 \mathrm{E}-10$ & $1.75 \mathrm{E}-10$ \\
\hline Sr90 & & $7.690 \mathrm{E}-05$ & $2.85 \mathrm{E}-06$ & $3.14 \mathrm{E}-08$ & $3.14 \mathrm{E}-08$ \\
\hline Tc99 & & 4.930E-07 & $1.83 \mathrm{E}-08$ & $3.23 \mathrm{E}-10$ & $3.23 \mathrm{E}-10$ \\
\hline Th228 & Progeny & $2.020 \mathrm{E}-02$ & 7.48E-04 & 7.47E-07 & 7.54E-07 \\
\hline Th232 & & 9.710E-02 & $3.60 \mathrm{E}-03$ & 5.73E-06 & 5.79E-06 \\
\hline U233 & & 7.990E-03 & $2.96 \mathrm{E}-04$ & $6.59 \mathrm{E}-08$ & $6.59 \mathrm{E}-08$ \\
\hline U234 & & 7.810E-03 & 2.89E-04 & $6.46 \mathrm{E}-08$ & 6.46E-08 \\
\hline U235 & & 7.281E-03 & 2.70E-04 & 6.05E-08 & 6.06E-08 \\
\hline U238 & & $6.980 \mathrm{E}-03$ & $2.59 \mathrm{E}-04$ & $5.81 \mathrm{E}-08$ & $5.81 \mathrm{E}-08$ \\
\hline Minimum & & & $1.38 \mathrm{E}-10$ & $1.39 \mathrm{E}-11$ & $1.39 \mathrm{E}-11$ \\
\hline Maximum & & & $3.60 \mathrm{E}-03$ & $5.73 \mathrm{E}-06$ & $5.79 \mathrm{E}-06$ \\
\hline
\end{tabular}


Table 2.3. Partition Coefficients $\left(K_{d} s\right)$ and Derived Groundwater Transfer Coefficients Used in the Groundwater Exposer Pathway Radionuclide Categories

\begin{tabular}{|c|c|c|}
\hline $\begin{array}{c}\text { Constituent/Radionuclid } \\
\mathrm{e}\end{array}$ & $\mathrm{K}_{\mathrm{d}}$ & $\begin{array}{c}\text { Groundwater Transfer } \\
\text { Coefficient }\end{array}$ \\
\hline${ }^{3} \mathrm{H}$ & $0^{(\mathrm{a})}$ & 100 \\
\hline $\mathrm{Be}$ & $30^{(\mathrm{b})}$ & 3 \\
\hline${ }^{14} \mathrm{C}$ & $0^{(\mathrm{a})}$ & 100 \\
\hline $\mathrm{Na}$ & $3^{(a)}$ & 33 \\
\hline $\mathrm{Cl}$ & $0^{(\mathrm{a})}$ & 100 \\
\hline $\mathrm{Mn}$ & $20^{(\mathrm{a})}$ & 5 \\
\hline $\mathrm{Fe}$ & $20^{(\mathrm{a})}$ & 5 \\
\hline Co & $10^{(\mathrm{a})}$ & 10 \\
\hline $\mathrm{Ni}$ & $15^{(\mathrm{a})}$ & 7 \\
\hline $\mathrm{Sr}$ & $10^{(\mathrm{a})}$ & 10 \\
\hline $\mathrm{Sb}$ & $0^{(\mathrm{a})}$ & 100 \\
\hline $\mathrm{Nb}$ & $100^{(\mathrm{b})}$ & 1 \\
\hline Mo & $0^{(\mathrm{a})}$ & 100 \\
\hline Tc & $0^{(\mathrm{a})}$ & 100 \\
\hline $\mathrm{Cd}$ & $15^{(\mathrm{a})}$ & 7 \\
\hline $\mathrm{I}$ & $0^{(a)}$ & 100 \\
\hline Cs & $50^{(a)}$ & 2 \\
\hline Lanathides Eu, Pm, Sm & $50^{(a)}$ & 2 \\
\hline $\mathrm{Ra}$ & $20^{(a)}$ & 5 \\
\hline Th & $50^{(\mathrm{a})}$ & 2 \\
\hline $\mathrm{U}$ & $0^{(\mathrm{a})}$ & 100 \\
\hline $\mathrm{Np}$ & $3^{(a)}$ & 33 \\
\hline $\mathrm{Pu}$ & $100^{(\mathrm{a})}$ & 1 \\
\hline $\mathrm{Am}, \mathrm{Cm}$ & $100^{(a)}$ & 1 \\
\hline $\mathrm{Ac}, \mathrm{Cf}$ & $100^{(\mathrm{a})}$ & 1 \\
\hline
\end{tabular}

(a) Serne and Wood 1990

(b) Serne 1994

\subsubsection{Hazardous Chemicals}

The methodology used to produce the RH-based HM values for chemicals used the PNNL developed Multimedia Environmental Pollutant Assessment System (MEPAS) code and default inputs of the MEPAS code, and, for the groundwater exposure pathway, used groundwater transfer partition coefficients $\left(\mathrm{K}_{\mathrm{d}}\right)$ from Serne and Wood, 1990.

The RH-based HM factors are based on near-field scenarios. In a near-field scenario, interest is focused on the doses an individual could receive at a particular location as a result of initial contamination or external sources (i.e., buried solid waste, contaminated soil, contaminated water, or contamination in air). This differs from a far-field scenario, defined as determining impacts of a particular release of hazardous material into a wide environment, such as the dose from releases from a stack to individuals or populations downwind. Near-field assumptions were used, since the only basic difference between near- 
field and far-field scenarios is dilution. In an RH analysis, the affect of dilution distance is accounted for in the Hazard Control (HC) parameter associated with relocation of material further from a receptor.

Descriptions of the exposure assumptions and hazardous chemical categories for each of the three exposure pathways are provided in the sections below, along with the respective HM factor look-up tables.

\section{Air Exposure Pathway}

This is a chronic exposure pathway that primarily poses long-term, large-scale risks to the public. Assumptions are that the exposed individual 1) lives continuously in contaminated air (chronic inhalation), 2) is continuously exposed to hazardous chemicals deposited on the ground surface, and 3) is continuously immersed in the airborne hazardous chemical plume. The values of the HM factor for the air exposure pathway are given in Table 2.4 for selected hazardous chemical exposures to the public and Table 2.5 for selected hazardous chemical exposures to workers.

\section{Surface Water Exposure Pathway}

This is a chronic exposure pathway that primarily poses long-term risks to public users of local surface water sources. Assumptions are that the exposed individual 1) eats food irrigated with contaminated surface water at an irrigation rate of $150 \mathrm{~L} / \mathrm{m}^{2} / \mathrm{mo}$ for $6 \mathrm{mo} / \mathrm{yr}, 2$ ) eats fish from the contaminated water, 3 ) is exposed to contaminated sediments along the bank, and 4) gets drinking water from the contaminated surface water. Resuspension of external hazardous chemicals deposited on the soil from irrigation is not considered. The values of the HM factor for the surface water exposure pathway are given in Table 2.4 for selected hazardous chemical exposures to the public and Table 2.5 for selected hazardous chemical exposures to workers.

\section{Groundwater Exposure Pathway}

This is a chronic exposure pathway that primarily poses long-term risks to public users of the local surface water sources. Groundwater is assumed to connect with surface water through infiltration, and exposure is via the surface water exposure pathway. No direct groundwater exposure via groundwater wells is assumed. Assumptions are that the exposed individual 1) eats food irrigated with surface water contaminated via connection with groundwater at an irrigation rate of $150 \mathrm{~L} / \mathrm{m}^{2} / \mathrm{mo}$ for $6 \mathrm{mo} / \mathrm{yr}$, 2) eats fish from the contaminated water, 3 ) is exposed to contaminated sediments along the bank, and 4) gets drinking water from the contaminated surface water. Resuspension of hazardous chemicals deposited on the soil from irrigation is not considered. The values of the HM factor for the groundwater exposure pathway are given in Table 2.4 for selected hazardous chemical exposures to the public and Table 2.5 for selected hazardous chemical exposures to workers. 
Table 2.4. HM Values for Public Exposures to Hazardous Chemicals

\begin{tabular}{|c|c|c|c|c|}
\hline & & $\mathrm{mg} / \mathrm{m} 3$ & $\mathrm{mg} / \mathrm{L}$ & $\mathrm{mg} / \mathrm{L}$ \\
\hline Chemical CAS & Name & HM Air & HM GW & HM SW \\
\hline 50328 & Benzo(a)pyrene & \begin{tabular}{|l|} 
4.50E-02 \\
\end{tabular} & 8.47E-02 & 1.40E-01 \\
\hline 56235 & Carbon Tetrachloride & $7.43 E-04$ & 4.41E-04 & 4.89E-04 \\
\hline 64175 & Ethanol & 4.73E-08 & 1.34E-08 & 1.34E-08 \\
\hline 64186 & Formic Acid & 6.01E-06 & 4.34E-08 & 4.37E-08 \\
\hline 67561 & Methanol & $1.20 E-06$ & 3.57E-07 & 3.57E-07 \\
\hline 67630 & Isopropanol & 7.72E-08 & 2.61E-08 & 2.61E-08 \\
\hline 67641 & Acetone & 1.69E-06 & 1.47E-06 & 1.47E-06 \\
\hline 71432 & Benzene & $2.89 E-04$ & 1.65E-04 & 1.66E-04 \\
\hline 71556 & 1,1,1-Trichloroethane & $3.05 E-04$ & 1.92E-04 & 1.97E-04 \\
\hline 75058 & Acetonitrile & 4.82E-05 & 6.36E-06 & 6.38E-06 \\
\hline 75092 & Dichloromethane & 1.84E-05 & 7.80E-06 & 7.84E-06 \\
\hline 75274 & Bromodichloromethane & 1.81E-05 & 3.40E-04 & 3.43E-04 \\
\hline 78933 & Methyl Ethyl Ketone & 2.46E-06 & 5.76E-07 & 5.77E-07 \\
\hline 79016 & Trichloroethylene & 5.49E-05 & 4.13E-04 & 4.26E-05 \\
\hline 91203 & Naphthalene & $1.03 E-04$ & 5.13E-05 & 5.17E-05 \\
\hline 91576 & 2-Methylnaphthalene & 5.97E-05 & 3.12E-05 & 3.25E-05 \\
\hline 106478 & p-Chloroaniline & $1.19 E-04$ & 9.10E-06 & 1.42E-05 \\
\hline 107211 & Ethylene glycol & 9.12E-06 & 1.89E-07 & 1.89E-07 \\
\hline 108883 & Toluene & 2.84E-06 & 1.52E-06 & $1.55 E-06$ \\
\hline 110543 & Hexanes & 3.15E-08 & 4.02E-06 & 4.91E-06 \\
\hline 117817 & Bis(2-ethylhexyl)phthalate & $1.58 E-03$ & 3.78E-03 & 4.19E-03 \\
\hline 126738 & Tributylphosphate & 1.84E-05 & 8.80E-06 & 1.99E-05 \\
\hline 127184 & Tetrachloroethylene & 3.23E-05 & 1.47E-04 & 1.68E-04 \\
\hline 205992 & Benzo(b)fluoranthene & 5.00E-03 & 6.29E-03 & 1.30E-02 \\
\hline 207089 & Benzo(k)fluoranthene & $1.90 E-03$ & 1.06E-03 & 1.51E-03 \\
\hline 1310732 & Sodium hydroxide & 2.42E-05 & 2.33E-06 & 2.34E-06 \\
\hline 1330207 & Xylene & 2.40E-06 & 1.22E-06 & 1.27E-06 \\
\hline 1336363 & PCBs & 5.52E-02 & 4.41E-02 & $1.89 E+00$ \\
\hline 1809194 & Dibutyl Phosphate & 2.99E-06 & 2.63E-07 & 2.73E-07 \\
\hline 6834920 & Silica & 7.41E-07 & 1.89E-07 & 1.95E-07 \\
\hline 7429905 & Aluminum ion & $1.96 \mathrm{E}-04$ & 8.36E-05 & 8.61E-05 \\
\hline 7439976 & Mercury & 5.84E-03 & 2.66E-04 & 5.76E-04 \\
\hline 7439987 & Molybdenum ion & 2.19E-04 & 7.16E-06 & 7.37E-06 \\
\hline 7440360 & Antimony ion & 2.14E-03 & 8.29E-05 & 1.30E-04 \\
\hline 7440393 & Barium ion & 2.04E-03 & 4.83E-07 & 7.51E-07 \\
\hline 7440417 & Beryllium & 2.63E-01 & 6.50E-03 & 1.25E-02 \\
\hline 7440473 & Chromium VI ion & 2.19E-01 & 8.01E-06 & 1.19E-05 \\
\hline 7440611 & Uranium ion & 2.24E-04 & 1.14E-05 & 1.31E-05 \\
\hline 7440622 & Vanadium ion & 2.00E-02 & 4.92E-06 & 5.07E-06 \\
\hline 7440677 & Zirconium ion & 1.02E-05 & 1.64E-06 & 2.32E-06 \\
\hline 7440702 & Calcium ion & $2.71 E-08$ & 2.07E-09 & 2.07E-09 \\
\hline 7447407 & Potassium ion & 1.03E-09 & 8.88E-11 & 2.71E-10 \\
\hline 7447418 & Lithium ion & 1.70E-07 & 1.54E-08 & 1.54E-08 \\
\hline 7601549 & Phosphate ion & 9.87E-04 & 1.44E-07 & 6.22E-08 \\
\hline 7647145 & Sodium ion & 3.00E-09 & 2.75E-10 & 3.07E-10 \\
\hline 7782414 & Fluoride ion & 5.02E-03 & 9.78E-07 & 9.94E-07 \\
\hline 7786303 & Magnesium ion & 4.09E-06 & 7.81E-10 & 8.75E-10 \\
\hline 14797558 & Nitrate ion & 1.14E-06 & 5.89E-08 & 5.87E-06 \\
\hline 14797650 & Nitrite ion & 6.03E-06 & 3.78E-07 & 9.33E-05 \\
\hline 15438310 & Iron ion & 3.33E-05 & 2.82E-08 & 1.71E-07 \\
\hline \multirow[t]{3}{*}{16065831} & Chromium III ion & 3.68E-07 & 4.48E-08 & 6.54E-08 \\
\hline & Min HM values & 1.03E-09 & 8.88E-11 & 2.71E-10 \\
\hline & Max HM values & 2.63E-01 & 8.47E-02 & $1.89 E+00$ \\
\hline
\end{tabular}


Table 2.5. HM Values for Worker Exposures to Hazardous Chemicals

\begin{tabular}{|c|c|c|c|c|}
\hline & & $\mathrm{mg} / \mathrm{m} 3$ & $\mathrm{mg} / \mathrm{L}$ & $\mathrm{mg} / \mathrm{L}$ \\
\hline Chemical CAS & Name & HM Air & HM GW & HM SW \\
\hline 50328 & Benzo(a)pyrene & 1.24E-02 & 4.14E-02 & 4.14E-02 \\
\hline 56235 & Carbon Tetrachloride & 3.12E-04 & 2.13E-04 & 3.69E-04 \\
\hline 64175 & Ethanol & 1.07E-08 & 6.46E-09 & 1.18E-08 \\
\hline 64186 & Formic Acid & 2.27E-06 & 7.20E-09 & 7.33E-09 \\
\hline 67561 & Methanol & 2.86E-07 & 1.72E-07 & 3.15E-07 \\
\hline 67630 & Isopropanol & 2.07E-08 & $1.25 \mathrm{E}-08$ & $2.28 E-08$ \\
\hline 67641 & Acetone & 8.40E-07 & 5.64E-07 & 9.84E-07 \\
\hline 71432 & Benzene & 1.43E-04 & 8.18E-05 & 1.53E-04 \\
\hline 71556 & 1,1,1-Trichloroethane & 1.52E-04 & 9.36E-05 & 1.69E-04 \\
\hline 75058 & Acetonitrile & 2.38E-05 & 2.40E-06 & 2.40E-06 \\
\hline 75092 & Dichloromethane & 3.43E-06 & $3.56 \mathrm{E}-06$ & 5.27E-06 \\
\hline 75274 & Bromodichloromethane & 2.72E-04 & 1.66E-04 & 3.01E-04 \\
\hline 78933 & Methyl Ethyl Ketone & 4.93E-07 & 2.71E-07 & 5.18E-07 \\
\hline 79016 & Trichloroethylene & 2.65E-05 & 2.04E-05 & 3.36E-05 \\
\hline 91203 & Naphthalene & 5.00E-05 & 2.56E-05 & 5.06E-05 \\
\hline 91576 & 2-Methylnaphthalene & 2.92E-05 & 1.55E-05 & 3.01E-05 \\
\hline 106478 & p-Chloroaniline & 3.57E-05 & 3.77E-06 & 3.79E-06 \\
\hline 107211 & Ethylene glycol & 7.14E-08 & 7.19E-09 & 7.32E-09 \\
\hline 108883 & Toluene & 1.30E-06 & 7.47E-07 & 1.40E-06 \\
\hline 110543 & Hexanes & 2.38E-06 & 1.98E-06 & 3.17E-06 \\
\hline 117817 & Bis(2-ethylhexyl)phthalate & 3.57E-05 & 1.83E-03 & 1.83E-03 \\
\hline 126738 & Tributylphosphate & 8.65E-06 & 4.02E-06 & 1.37E-06 \\
\hline 127184 & Tetrachloroethylene & 5.53E-06 & $7.21 E-05$ & 6.46E-03 \\
\hline 205992 & Benzo(b)fluoranthene & 1.74E-03 & 3.08E-03 & 3.08E-03 \\
\hline 207089 & Benzo(k)fluoranthene & 8.22E-04 & 5.19E-04 & 5.19E-04 \\
\hline 1310732 & Sodium hydroxide & 1.02E-05 & 1.03E-06 & 1.03E-06 \\
\hline 1330207 & Xylene & 1.19E-06 & 6.07E-07 & 1.20E-06 \\
\hline 1336363 & PCBs & 1.57E-02 & 2.11E-02 & 2.11E-02 \\
\hline 1809194 & Dibutyl Phosphate & 1.10E-06 & 1.14E-07 & 1.16E-07 \\
\hline 6834920 & Silica & 2.04E-07 & 8.39E-08 & 8.40E-08 \\
\hline 7429905 & Aluminum ion & 1.02E-05 & 3.60E-05 & 3.60E-05 \\
\hline 7439976 & Mercury & $1.66 \mathrm{E}-03$ & 4.85E-05 & 4.85E-05 \\
\hline 7439987 & Molybdenum ion & 9.99E-05 & 2.90E-06 & 2.90E-06 \\
\hline 7440360 & Antimony ion & 9.99E-04 & 3.63E-05 & 3.63E-05 \\
\hline 7440393 & Barium ion & 1.02E-03 & 2.09E-07 & 2.09E-07 \\
\hline 7440417 & Beryllium & 1.71E-02 & 3.13E-03 & 5.77E-03 \\
\hline 7440473 & Chromium VI ion & $1.09 E-01$ & 3.35E-06 & 3.36E-06 \\
\hline 7440611 & Uranium ion & 1.02E-04 & 4.95E-06 & 4.96E-06 \\
\hline 7440622 & Vanadium ion & 9.99E-03 & 2.07E-06 & 2.07E-06 \\
\hline 7440677 & Zirconium ion & 4.08E-06 & 7.52E-07 & 7.56E-07 \\
\hline 7440702 & Calcium ion & 8.40E-09 & 8.50E-10 & $8.50 \mathrm{E}-10$ \\
\hline 7447407 & Potassium ion & $2.80 E-10$ & 2.81E-11 & 2.82E-11 \\
\hline 7447418 & Lithium ion & $2.38 E-08$ & 2.40E-09 & 2.40E-09 \\
\hline 7601549 & Phosphate ion & 4.93E-03 & 3.13E-08 & 3.13E-08 \\
\hline 7647145 & Sodium ion & 4.76E-10 & 4.80E-11 & 4.80E-11 \\
\hline 7782414 & Fluoride ion & 2.51E-03 & 2.40E-07 & 2.40E-07 \\
\hline 7786303 & Magnesium ion & 2.04E-06 & $2.88 E-10$ & $2.89 \mathrm{E}-10$ \\
\hline 14797558 & Nitrate ion & 8.93E-08 & 9.06E-09 & 9.06E-09 \\
\hline 14797650 & Nitrite ion & 1.43E-06 & 1.44E-07 & 1.44E-07 \\
\hline 15438310 & Iron ion & 1.66E-05 & 1.12E-08 & 1.13E-08 \\
\hline \multirow[t]{3}{*}{16065831} & Chromium III ion & 1.43E-07 & 1.91E-08 & 1.92E-08 \\
\hline & Min HM values & $2.80 E-10$ & 2.81E-11 & 2.82E-11 \\
\hline & Max HM values & 1.09E-01 & 4.14E-02 & 4.14E-02 \\
\hline
\end{tabular}




\subsection{Hazard Control Factors}

The Hazard Control (HC) factors represent the worth, in terms of reduction in hazard, of specific risk management actions. These actions include risk management activities such as vitrification or grouting of waste materials; separation, reduction or removal of specific constituents from a waste stream; relocation of waste material away from receptors or vulnerable pathways; repackaging or stabilization of waste material.

In calculating the relative hazard $(\mathrm{RH})$ of a waste type at a site, these $\mathrm{HC}$ factors should be estimated from existing risk assessment data, where possible. In many cases there will be specific risk assessments for which generalizations can be made to roughly estimate the worth of a specific risk management action. Often there are risk estimates for specified accident conditions in a Safety Analysis Report (SAR) or safety basis document that can be examined to get a rough estimate of the worth of a specific action. In cases where no such risk assessment data are available, HC look-up tables are provided to use in estimating the $\mathrm{HC}$ factor.

The HC factor is used to assess changes in the relative hazard of a contaminant or waste based on changes in its physical condition or location due to waste management or environmental restoration actions. The $\mathrm{HC}$ factor for a specific hazard reduction measure (e.g., capping) represents the reduction in hazard associated with that measure (i.e., the post-action hazard divided by the pre-action hazard). This factor, in conjunction with the other factors representing contaminant inventory and the nature of the contaminant and potential contaminant exposure mechanism, allows the evaluation of the potential reduction in hazard associated with a variety of potential waste management or environmental restoration actions.

\subsubsection{Hazard vs. Risk}

The term "hazard" as used here relates to potential health effects associated with a contaminant or waste material, assuming that it is already released to the environment. In contrast, the estimates of risk that are typically used to assess the need for or effectiveness of potential environmental restoration or waste management activities are computed taking into account both potential health effects (i.e., hazard) and the likelihood or probability of contaminant release and subsequent exposure. In simple terms, hazard and risk are related as follows:

$$
\text { Risk }=\text { Probability of Release or Exposure } \times \text { Hazard }
$$

Therefore, the term hazard as used here relates only to the intrinsic danger to health that would be posed by the contaminant or waste material in the environment in its current physical form and location. Changes in physical form or location of a contaminant or waste that alter its hazard can also change its associated risk. However, it is not necessarily true that that a contaminant or waste with a relatively high hazard poses a high risk in the sense that is usually discussed in risk assessments.

This relationship between risk and hazard can be used to facilitate calculating HCs. If the risks are compared for a contaminant or waste in alternative physical conditions or locations, but having the same probability of release or exposure, the relative hazards posed by those alternative conditions or locations are related in the same proportion as the relative risks.

Therefore, using standard risk estimating techniques in a manner that makes the probability of release or exposure constant allows direct estimation of the change in hazard associated with potential waste management or environmental restoration actions. The simplest way to "fix" the probability of release or 
exposure is to assume that the contaminant or waste has already been released. This is the approach that was used to estimate the changes in hazard (i.e., HCs) discussed in the following sections.

\subsubsection{Factors Affecting the HC}

Five aspects of a contaminant or waste that have significant impacts relative to assessing its hazard are described in the following sections.

\section{Toxicity or Radiological Nature}

A contaminant's toxic or radiological characteristics determine the severity of its health effects when exposure occurs. Differences among contaminants in this regard are accounted for in the health effects data used in risk assessment methodologies. While typical waste management or environmental restoration activities may affect the amount of contaminant present, they don't generally affect its toxic or radiological nature. Therefore, this aspect of potential hazard is not addressed in assessing HCs for such actions. However, since this factor affects hazard, but not HCs, this aspect of hazard is addressed by the $\mathrm{HM}$ factor in the relative hazard calculation.

\section{Chemical Nature}

The second key aspect of a contaminant affecting its hazard, or the impact of hazard control measures on it, is its chemical nature. Organic and inorganic contaminants generally behave differently both in their environmental transport and their response to treatment. In addition, the hazard associated with a radioactive element changes spontaneously as it decays.

\section{Mobility}

A third aspect of a contaminant or waste affecting its hazard is its mobility in the environment. Contaminants that move more readily through the environment are more likely transport to off-site receptors and thereby pose health risks to those receptors than those that are relatively immobile. In addition, slow transport of radioactive elements allows time for these contaminants to decay prior to exposing receptors.

\section{Physical Form}

The physical form of a contaminant or waste has a significant impact on its hazard. The physical form of a contaminant or waste affects its availability for transport (i.e., the rate at which it is released). For example, liquid wastes are generally easier to transport than solid wastes, and are therefore more hazardous. In addition, solid waste that has been treated to immobilize contaminants (e.g., cemented or vitrified) allows contaminants to be released more slowly for transport and is therefore less hazardous.

\section{Location}

The final aspect of a contaminant or waste that affects its hazard is its location. A contaminant released to the environment in an isolated location with long transport pathways to receptors is intrinsically less hazardous than the same contaminant in a location that allows rapid transport of it to receptors. In addition, the hazard reduction associated with a waste management or environmental restoration action will vary depending on the waste's location. 


\subsubsection{Approach for Estimating HCs}

Calculating site-specific HCs for a variety of potential waste management or environmental restoration actions requires taking all these considerations into account. The approach used here is to compare the calculated risks for site-specific conditions before and after such actions are taken to infer the corresponding reduction in hazard, as suggested by the relationship between risk and hazard discussed above. Such risk calculations can be performed with any risk calculation methodology that allows parametric variation of the key parameters discussed above. For the illustrative calculations discussed below, the Remedial Action Assessment System (RAAS) was used (Bagaasen et al. 1996). RAAS was developed by PNNL for DOE as an analytical tool for defining and evaluating alternative remedial action strategies for DOE waste sites. The RAAS methodology is useful for this sort of analysis because it allows direct variation of the key waste form and waste location parameters described above.

RAAS includes elements of the Multimedia Environmental Pollutant Assessment System (MEPAS)(Droopo et al. 1989) for calculating risk for the maximum exposed individual (MEI) as a result of transport of contaminants to potential receptors. As discussed above, comparison of these MEI risks as key waste form or location factors are varied allows calculation of the corresponding HC.

\section{Waste Form Variations}

Four different waste forms were analyzed in the following illustrations: liquid waste, soil waste, cemented or grouted waste, and vitrified waste. These classifications represent the most likely forms that will be encountered in assessing hazard reduction measures, and many of the key hazard reduction measures result in a transition from one of these physical states to another.

The relative hazards associated with these states were calculated by comparing the risk associated with equivalent amounts of contaminant already released to the environment in these states. For the solid waste forms (soil waste, cemented or grout wastes, and vitrified waste), in-situ wastes of the corresponding waste forms or states were modeled, and the corresponding risk calculated. Since these wastes were already released, the "probability of release or exposure" aspect of the risk calculation is the same (i.e., probability of release or exposure is "1.0"), and therefore the risk measure also represents the relative hazards. The liquid waste state was modeled as a pond containing the same amount of the contaminant as the soil site. Again, the contaminant is modeled as already released, so the corresponding calculated risk can be used to assess changes in hazard.

These calculations, performed for each site of interest, result in the following factors that are subsequently used in $\mathrm{HC}$ calculation:

$$
\begin{aligned}
\mathrm{GF} & =\frac{\text { risk associated with unit of contaminant in cemented/grouted waste }}{\text { risk associated with unit of contaminant in soil waste }} \\
\mathrm{VF} & =\frac{\text { risk associated with unit of contaminant in vitrified waste }}{\text { risk associated with unit of contaminant in soil waste }} \\
\mathrm{SF} & =\frac{\text { risk associated with unit of contaminant in liquid waste }}{\text { risk associated with unit of contaminant in soil waste }}
\end{aligned}
$$

\section{Hazard Reduction Measures}

HCs were estimated for a variety of waste treatment or environmental restoration activities involving the waste form changes described above. In addition, the following similar factors were defined or estimated 
(also using the RAAS methodology) for other actions typically occurring as part of waste treatment and environmental restoration:

$$
\begin{aligned}
& \text { FMR } \quad=\text { Fraction of Medium Removed (in contaminated medium) } \\
& \text { FCR } \quad=\text { Fraction Contaminant Remaining (after separation/destruction treatment) } \\
& \mathrm{CF} \quad=\frac{\text { risk associated with unit of contaminant in capped site }}{\text { risk associated with unit of contaminant in soil waste site }} \\
& \mathrm{RF} \quad=\frac{\text { risk associated with unit of contaminant in alternative waste site }}{\text { risk associated with unit of contaminant in original soil waste }}
\end{aligned}
$$

The first two of these (FMR and FCR) relate to actions that change the inventory or contaminant. In general, the hazard associated with a contaminant is in proportion to its inventory. If waste is removed from a contaminated site for treatment, the fraction remaining (1-FMR) retains its initial hazard level, while the fraction removed (FMR) may have a different hazard level depending on how it is treated and subsequently disposed of). Note that this formulation assumes that contaminant removed is proportional to medium removed. If this is not the case, then the fraction of the contaminant remaining should be used rather than the fraction of the medium remaining. Similarly, FCR is used to assess the change in hazard associated with in situ or ex situ treatment that separates or destroys the contaminant, thereby changing the contaminant inventory and corresponding hazard. These two factors (FMR and FCR) are provided to allow the user to make adjustments for inventory reductions within the $\mathrm{HC}$ factor; however, these inventory adjustments can also be made by directly adjusting the respective Q values of the RH equation. It is left to the user's discretion to decide where best to account for inventory changes associated with specific risk/hazard management actions, but care should be taken not to double count the inventory reductions. Table 2.6 defines the $\mathrm{HC}$ for a variety of potential waste management or environmental restoration actions, in terms of the various hazard reduction factors previously defined.

\section{Contaminant Categories}

Ideally, the various factors defined above could be calculated for every contaminant of concern and then used as appropriate to estimate HCs for waste management or environmental restoration actions of interest. The RAAS methodology contains the necessary physical, chemical, and health effect data for over 400 organic, inorganic, and radioactive contaminants of potential concern. However, performing such comprehensive calculations is time consuming, and probably not warranted in terms of the incremental insight provided. Rather, representative contaminants can be selected and used as surrogates for specific contaminants. As discussed previously, the key contaminant-specific differences of concern relate to the chemical or radiological nature of the contaminant and its mobility.

For the purposes of the illustrative HC estimates developed here, a set of contaminant categories were developed that represent potential variation in these key contaminant characteristics, and a representative contaminant selected for each category. These categories and representative contaminants are shown in Table 2.7. 
Table 2.6. Hazard Reduction Measures with Generic Hazard Control (HC) Factors

\begin{tabular}{|c|c|c|}
\hline \multicolumn{2}{|l|}{ Hazard Reduction Measure } & HC Factor \\
\hline \multirow{3}{*}{$\begin{array}{l}\text { removal, treatment, and } \\
\text { disposal of treated medium in } \\
\text { original environmental setting }\end{array}$} & $\begin{array}{l}\text { treatment to separate or } \\
\text { destroy contaminants }\end{array}$ & 1 - FMR (1 - FCR) \\
\hline & $\begin{array}{l}\text { cement/package removed } \\
\text { medium }\end{array}$ & $1-\operatorname{FMR}(1-\mathrm{GF})$ \\
\hline & $\begin{array}{l}\text { vitrify/package removed } \\
\text { medium }\end{array}$ & $1-\mathrm{FMR}(1-\mathrm{VF})$ \\
\hline \multirow{5}{*}{$\begin{array}{l}\text { removal, treatment, and/or } \\
\text { remote disposal of treated } \\
\text { medium either off-site or in } \\
\text { alternative environmental } \\
\text { setting on-site }\end{array}$} & off-site disposal (or treatment) & 1 - FMR \\
\hline & $\begin{array}{l}\text { direct disposal in alternative } \\
\text { ES on-site }\end{array}$ & $1-\mathrm{FMR}(1-\mathrm{RF})$ \\
\hline & $\begin{array}{l}\text { treat to separate or destroy } \\
\text { contaminants \& replace in } \\
\text { alternative environmental } \\
\text { setting on-site }\end{array}$ & $1-\mathrm{FMR}[1-(\mathrm{FCR})(\mathrm{RF})]$ \\
\hline & $\begin{array}{l}\text { cement/package \& replace in } \\
\text { alternative environmental } \\
\text { setting on-site }\end{array}$ & $1-\mathrm{FMR}[1-(\mathrm{GF})(\mathrm{RF})]$ \\
\hline & $\begin{array}{l}\text { vitrify/package \& replace in } \\
\text { alternative environmental } \\
\text { setting on-site }\end{array}$ & $1-\mathrm{FMR}[1-(\mathrm{VF})(\mathrm{RF})]$ \\
\hline \multirow{4}{*}{$\begin{array}{l}\text { in situ treatment or } \\
\text { containment }\end{array}$} & in situ separation/destruction & FCR \\
\hline & grout in place & GF \\
\hline & in situ vitrification & $\mathrm{VF}$ \\
\hline & capping & $\mathrm{CF}$ \\
\hline \multirow{4}{*}{ ex situ waste treatment } & solidify liquid waste & SF \\
\hline & separate/destroy contaminants & FCR \\
\hline & cement solid waste & GF \\
\hline & vitrify solid waste & VF \\
\hline
\end{tabular}

FMR $=$ Fraction of contaminated Medium Removed for treatment

FCR $=$ Fraction of Contaminant Remaining (final concentration divided by initial concentration) after treatment to separate or destroy contaminant

$\mathrm{GF}=$ Grout Factor $=($ risk associated with unit of contaminant in grouted waste $) /($ risk associated with a unit contaminant in untreated waste)

$\mathrm{VF}=$ Vitrification Factor $=$ (risk associated with unit contaminant in vitrified waste) $/$ (risk associated with a unit of contaminant in waste in original location)

$\mathrm{RF}=$ Relocation Factor $=($ risk associated with a unit of contaminant in relocated waste $) /($ risk associated with a unit of contaminant in waste in original location)

$\mathrm{CF}=$ Capping Factor $=$ (risk associated with a unit of contaminant in waste after cap is applied) $/($ risk associated with a unit of contaminant in waste in original location prior to applying cap)

$\mathrm{SF}=$ Solidification Factor $=($ risk associated with unit of contaminant in solidified waste $) /($ risk associated with a unit of contaminant in liquid waste) 
Table 2.7. Contaminant Categories

\begin{tabular}{|l|l|l|l|l|l|l|}
\hline \multirow{2}{*}{$\begin{array}{l}\text { contaminant } \\
\text { type }\end{array}$} & organic & $\begin{array}{l}\text { low mobility } \\
\text { long half-life } \\
\text { radionuclide }\end{array}$ & $\begin{array}{l}\text { short } \\
\text { half-life } \\
\text { radionuclide }\end{array}$ & organic & $\begin{array}{l}\text { inorganic or } \\
\text { long half-life } \\
\text { radionuclide }\end{array}$ & $\begin{array}{l}\text { short } \\
\text { half-life } \\
\text { radionuclide }\end{array}$ \\
\hline $\begin{array}{l}\text { representative } \\
\text { contaminant(s) }\end{array}$ & PCB & $\begin{array}{l}\mathrm{Hg} \\
{ }^{239} \mathrm{Pu}\end{array}$ & ${ }^{137} \mathrm{Cs}$ & TCE & $\begin{array}{l}\text { As } \\
99\end{array}$ & ${ }^{3} \mathrm{H}$ \\
\hline
\end{tabular}

\section{Illustrative HC Calculations}

The methodology described above was used to develop generalized HC look-up tables for use as default values when more accurate $\mathrm{HC}$ values are not available from applicable risk assessments or other such studies on the facilities or operations in question. Default $\mathrm{HC}$ values for the soil to groundwater to surface water pathway for arid sites are available in Table 2.8. Default $\mathrm{HC}$ values for the soil to groundwater to surface water pathway for humid sites are available in Table 2.9. Default HC values for the air pathway for arid sites are available in Table 2.10. Default $\mathrm{HC}$ values for the air pathway for humid sites are available in Table 2.11. 
Table 2.8. Arid Site Guidance Table for Estimating Default HC Factors (Log Scale)

Arid Site Guidance Table for Estimating HC Factors (Log Scale)

Pathway: Soil $=>G W=>S W$

\begin{tabular}{|c|c|c|c|c|c|c|}
\hline \multirow[b]{2}{*}{ Risk Reduction Activity } & \multicolumn{3}{|c|}{ High Mobility } & \multicolumn{3}{|c|}{ Low Mobility } \\
\hline & $\begin{array}{l}\text { Organic } \\
\text { (no or long } \\
\text { Bio. } \mathrm{T}_{1 / 2} \text { ) }\end{array}$ & \begin{tabular}{|c|} 
Inorganic or \\
Long $\mathrm{T}_{1 / 2}$ \\
Rad.
\end{tabular} & $\begin{array}{c}\text { Short } \mathrm{T}_{1 / 2} \\
\operatorname{Rad}\end{array}$ & $\begin{array}{c}\text { Organic } \\
\text { (no or long } \\
\text { Bio. } \mathrm{T}_{1 / 2} \text { ) }\end{array}$ & \begin{tabular}{c|} 
Inorganic \\
or Long \\
$\mathrm{T}_{1 / 2} \mathrm{Rad}$ \\
\end{tabular} & $\begin{array}{l}\text { Short } \mathrm{T}_{1 / 2} \\
\operatorname{Rad}\end{array}$ \\
\hline Retrieval w/Sludge/Soil Washing & \multicolumn{6}{|c|}{$\begin{array}{l}\text { Specific contaminant quantity decrease by washing efficiency fraction }(\mathrm{Qc} * \text { Removal } \\
\text { Fraction) } \mathrm{HCc}=\text { Removal Fraction }\end{array}$} \\
\hline Retrieval w/Contaminant Separation & \multicolumn{6}{|c|}{$\begin{array}{l}\text { Specific Contaminant quantity decrease of separated contaminants }(\mathrm{Qc} * \text { Separation } \\
\text { Fraction) } \mathrm{HCc}=\text { Separation Fraction }\end{array}$} \\
\hline Vitrification to Offsite & E-12 & \begin{tabular}{|r|}
$\mathrm{E}-12$ \\
\end{tabular} & E-12 & \begin{tabular}{|r|} 
E-12 \\
\end{tabular} & E-12 & E-12 \\
\hline Vitrification to Site & E-10 & E-4 to E-6 & E-4 to E-6 & E-10 & E-3 & E-5 to E-9 \\
\hline Cemented Solidification & E-1 to E-3 & E-1 to E-3 & $\mathrm{E}-1$ to $\mathrm{E}-3$ & 1 to $\mathrm{E}-1$ & 1 to $\mathrm{E}-1$ & 1 to $\mathrm{E}-1$ \\
\hline $\begin{array}{l}\text { Liquid to Solid Stabilization } \\
\text { (solidification) }\end{array}$ & $\mathrm{E}-1$ to $\mathrm{E}-3$ & $\mathrm{E}-2$ to $\mathrm{E}-3$ & $E-3$ to $E-4$ & E-4 to E-7 & E-4 to E-7 & E-4 to E-7 \\
\hline Chemically Immobilize & E-1 to E-3 & $\mathrm{E}-1$ to $\mathrm{E}-3$ & E-1 to E-3 & 1 & 1 & E-2 \\
\hline $\begin{array}{l}\text { Water Removal from Wet Storage } \\
\text { Facilities }\end{array}$ & $\mathrm{E}-1$ to $\mathrm{E}-3$ & $\mathrm{E}-1$ to $\mathrm{E}-3$ & $\mathrm{E}-1$ to $\mathrm{E}-3$ & $\mathrm{E}-4$ to $\mathrm{E}-7$ & E-4 to E-7 & E-4 to E-7 \\
\hline Safe Store to Allow Decay to Offsite & \multicolumn{6}{|c|}{$\begin{array}{l}\text { Quantity Decrease (1-Fraction of Contaminant Inventory Eliminated) (Q decreased) } \\
\mathrm{W} / \mathrm{HC}=1\end{array}$} \\
\hline Thermal Stabilization & E-12 & E-1 to E-3 & 1 to $\mathrm{E}-2$ & \begin{tabular}{|r|}
$\mathrm{E}-12$ \\
\end{tabular} & 1 to E-1 & \\
\hline Macroencapsulation & 1 & 1 to $\mathrm{E}-2$ & 1 to $\mathrm{E}-2$ & 1 & 1 to $\mathrm{E}-1$ & \\
\hline Amalgamation (e.g., Hg) & E-1 to E-3 & E-1 to E-3 & E-1 to E-3 & & & \\
\hline $\begin{array}{l}\text { Removal from Pathway } \\
\text { Repackaging/Containerization for } \\
\text { Disposal Onsite }\end{array}$ & \multicolumn{6}{|c|}{$\begin{array}{l}\text { Volume Decrease (1-Fract. Contaminant Inv. Elim.*Disposal Multiplier) No } \\
\text { forget to add the quantity removed from this pathway to the new pathway }\end{array}$} \\
\hline Disposal/Bury W/O Cap & \begin{tabular}{r|}
1 \\
\end{tabular} & \begin{tabular}{|r|}
1 \\
\end{tabular} & 1 & \begin{tabular}{r|}
1 \\
\end{tabular} & 1 & 1 \\
\hline Disposal/Bury W/ HI Cap & E-2 & E-2 to E-3 & E-4 & E-1 & E-1 & E-3 \\
\hline $\begin{array}{l}\text { Removal from Pathway } \\
\text { Repackaging/Containerization for } \\
\text { Disposal Offsite }\end{array}$ & \multicolumn{6}{|c|}{ Quantity Decreased (Multiply by Fraction of Contaminant Quantity Eliminated) } \\
\hline $\begin{array}{l}\text { Increase Transport Time to Receptor } \\
\text { (that is, move away from population or } \\
\text { env. of concern) }\end{array}$ & E-1 to E-2 & $\mathrm{E}-1$ to $\mathrm{E}-8$ & E-1 to E-10 & $\mathrm{E}-1$ to $\mathrm{E}-2$ & E-1 to E-8 & $\mathrm{E}-1$ to $\mathrm{E}-10$ \\
\hline Pu Stabilization & 1 & 1 & 1 & 1 & 1 & 1 \\
\hline Packaging W/ Geologic Disposal & E-10 & E-10 & E-10 & E-10 & E-10 & $\mathrm{E}-10$ \\
\hline Packaging W/ WIPP Disposal (Offsite) & E-12 & E-12 & $\mathrm{E}-12$ & $\mathrm{E}-12$ & E-12 & E-12 \\
\hline Equipment/Facility/Area D\&D & \multicolumn{6}{|c|}{ Quantity Decreased (Fraction of Contaminant Inventory Eliminated) } \\
\hline Incineration & $\begin{array}{r}\text { E-12 } \\
\end{array}$ & \begin{tabular}{r|}
1 \\
\end{tabular} & 1 & \begin{tabular}{|r|}
$E-12$ \\
\end{tabular} & 1 & 1 \\
\hline Soil Vapor Extraction & \multicolumn{6}{|c|}{$\begin{array}{l}\text { Specific contaminant quantity decreas by vapor extraction effeciency (Qc * Extraction } \\
\text { Fraction) HCc = Vapor Extraction Fraction Note: The extracted fraction of the soil Qc } \\
\text { will need to be added to the air pathway, unless it is captured }\end{array}$} \\
\hline Disposal RCRA Facility Offsite & E-12 & E-12 & E-12 & E-12 & E-12 & E-12 \\
\hline
\end{tabular}

Note: Do not consider these estimated $\mathrm{HC}$ values as "hard and fast" values, feel free to adjust as appropriate. This table is only meant to provide guidance on estimating $\mathrm{HC}$ factors. Best scientific judgment should be considered when assigning $\mathrm{HC}$ values. For example, consider the degree and thoroughness of the control application. In the case of increasing transport time to receptor, consider the distance and conditions of normal transport when picking an $\mathrm{HC}$ value to represent moving a source away from the receptor(s). Maintaining consistency in assigning $\mathrm{HC}$ values is very important.

Note: Table assumes appropriate application of the technology being considered.

Note: For log scaling purposes set zero to equal E-12 (i.e., $1 \times 10^{-12}$ ). 
Table 2.9. Humid Site Guidance Table for Estimating Default HC Factors (Log Scale)

Humid Site Guidance Table for Estimating HC Factors (Log Scale)

Pathway: Soil $=>G W=>S W$

\begin{tabular}{|c|c|c|c|c|c|c|}
\hline \multirow[b]{2}{*}{ Risk Reduction Activity } & \multicolumn{3}{|c|}{ High Mobility } & \multicolumn{3}{|c|}{ Low Mobility } \\
\hline & $\begin{array}{l}\text { Organic } \\
\text { (no or long } \\
\text { Bio. } \mathrm{T}_{1 / 2} \text { ) }\end{array}$ & \begin{tabular}{|} 
Inorganic or \\
Long $\mathrm{T}_{1 / 2}$ \\
Rad.
\end{tabular} & $\begin{array}{l}\text { Short } \mathrm{T}_{1 / 2} \\
\operatorname{Rad}\end{array}$ & $\begin{array}{c}\text { Organic } \\
\text { (no or long } \\
\left.\text { Bio. } \mathrm{T}_{1 / 2}\right)\end{array}$ & \begin{tabular}{c|} 
Inorganic \\
or Long \\
$\mathrm{T}_{1 / 2} \mathrm{Rad}$
\end{tabular} & $\begin{array}{l}\text { Short } \mathrm{T}_{1 / 2} \\
\operatorname{Rad}\end{array}$ \\
\hline Retrieval w/Sludge/Soil Washing & \multicolumn{6}{|c|}{$\begin{array}{l}\text { Specific contaminant quantity decrease by washing efficiency fraction }\left(\mathrm{Qc}^{*}\right. \\
\text { Removal Fraction) } \mathrm{HCc}=\text { Removal Fraction }\end{array}$} \\
\hline Retrieval w/Contaminant Separation & \multicolumn{6}{|c|}{$\begin{array}{l}\text { Specific Contaminant quantity decrease of separated contaminants }(\mathrm{Qc} * \\
\text { Separation Fraction) } \mathrm{HCc}=\text { Separation Fraction }\end{array}$} \\
\hline Vitrification to Offsite & $\begin{array}{r}\text { E-12 } \\
\end{array}$ & \begin{tabular}{r|}
$\mathrm{E}-12$ \\
\end{tabular} & \begin{tabular}{|r|}
$\mathrm{E}-12$ \\
\end{tabular} & \begin{tabular}{r|}
$\mathrm{E}-12$ \\
\end{tabular} & $\mathrm{E}-12$ & E-12 \\
\hline Vitrification to Site & E-10 & E-4 to E-6 & E-4 to E-6 & E-10 & E-3 & E-5 to E-9 \\
\hline Cemented Solidification & 1 & E-1 & E-1 & 1 & E-1 & E-1 \\
\hline $\begin{array}{l}\text { Liquid to Solid Stabilization } \\
\text { (solidification) }\end{array}$ & $\mathrm{E}-1$ to $\mathrm{E}-3$ & $\mathrm{E}-2$ to $\mathrm{E}-3$ & $E-3$ to $E-4$ & E-4 to E-7 & E-4 to E-7 & E-4 to E-7 \\
\hline Chemically Immobilize & E-1 to E-3 & E-1 to E-3 & E-1 to E-3 & 1 & 1 & E-2 \\
\hline $\begin{array}{l}\text { Water Removal from Wet Storage } \\
\text { Facilities }\end{array}$ & $\mathrm{E}-1$ to $\mathrm{E}-3$ & $\mathrm{E}-1$ to $\mathrm{E}-3$ & $\mathrm{E}-1$ to $\mathrm{E}-3$ & E-4 to E-7 & $\mathrm{E}-4$ to $\mathrm{E}-7$ & E-4 to E-7 \\
\hline Safe Store to Allow Decay to Offsite & \multicolumn{6}{|c|}{$\begin{array}{l}\text { Quantity Decrease (1-Fraction of Contaminant Inventory Eliminated) (Q } \\
\text { decreased) } \mathrm{W} / \mathrm{HC}=1\end{array}$} \\
\hline Thermal Stabilization & E-12 & E-1 to E-3 & 1 to $\mathrm{E}-2$ & E-12 & 1 to $\mathrm{E}-1$ & \\
\hline Macroencapsulation & 1 & 1 to $\mathrm{E}-2$ & 1 to $\mathrm{E}-2$ & 1 & 1 to $\mathrm{E}-1$ & \\
\hline Amalgamation (e.g., Hg) & E-1 to E-3 & E-1 to E-3 & E-1 to E-3 & & & \\
\hline $\begin{array}{l}\text { Removal from Pathway } \\
\text { Repackaging/Containerization for } \\
\text { Disposal Onsite }\end{array}$ & \multicolumn{6}{|c|}{$\begin{array}{l}\text { Volume Decrease (1-Fract. Contaminant Inv. Elim.*Disposal Multiplier) } \\
\text { Note: Don't forget to add the quantity removed from this pathway to the new } \\
\text { pathway }\end{array}$} \\
\hline Disposal/Bury W/O Cap & 1 & \begin{tabular}{r|}
1 \\
\end{tabular} & \begin{tabular}{r|}
1 \\
\end{tabular} & 1 & $\begin{array}{r}1 \\
\end{array}$ & \\
\hline Disposal/Bury W/ HI Cap & E-3 & E-3 to E-4 & E-5 & E-1 & E-1 & E-3 \\
\hline $\begin{array}{l}\text { Removal from Pathway } \\
\text { Repackaging/Containerization for } \\
\text { Disposal Offsite }\end{array}$ & \multicolumn{6}{|c|}{$\begin{array}{l}\text { Quantity Decreased (Multiply by Fraction of Contaminant Quantity } \\
\text { Eliminated) }\end{array}$} \\
\hline $\begin{array}{l}\text { Increase Transport Time to Receptor } \\
\text { (that is, move away from population or } \\
\text { env. of concern) }\end{array}$ & E-2 & E-2 & E-3 & E-2 & E-2 & E-3 \\
\hline Pu Stabilization & 1 & 1 & 1 & 1 & 1 & \\
\hline Packaging W/ Geologic Disposal & E-10 & E-10 & E-10 & E-10 & E-10 & $\mathrm{E}-10$ \\
\hline Packaging W/ WIPP Disposal (Offsite) & $\mathrm{E}-12$ & E-12 & E-12 & E-12 & $\mathrm{E}-12$ & E-12 \\
\hline Incineration & E-12 & 1 & 1 & E-12 & 1 & \\
\hline Soil Vapor Extraction (Organics) & \multicolumn{6}{|c|}{$\begin{array}{l}\text { Specific contaminant quantity decrease by vapor extraction efficiency. (Qc * } \\
\text { Extraction Efficiency) HCc = Vapor Extraction Fraction Note: the extracted } \\
\text { fraction of the soil Qc will need to be added to the air pathway, unless it is } \\
\text { captured. }\end{array}$} \\
\hline Equipment/Facility/Area D\&D & \multicolumn{6}{|c|}{ Quantity Decreased (Fraction of Contaminant Inventory Eliminated) } \\
\hline Disposal RCRA Facility Offsite & $\mathrm{E}-12$ & \begin{tabular}{r|}
$\mathrm{E}-12$ \\
\end{tabular} & \begin{tabular}{|r|}
$\mathrm{E}-12$ \\
\end{tabular} & $\mathrm{E}-12$ & E-12 & E-12 \\
\hline
\end{tabular}

Note: Do not consider these estimated $\mathrm{HC}$ values as "hard and fast" values, feel free to adjust as appropriate. This table is only meant to provide guidance on estimating $\mathrm{HC}$ factors. Best scientific judgment should be considered when assigning $\mathrm{HC}$ values. For example, consider the degree and thoroughness of the control application. In the case of increasing transport time to receptor, consider the distance and conditions of normal transport when picking an $\mathrm{HC}$ value to represent moving a source away from the receptor(s). Maintaining consistency in assigning HC values is very important.

Note: Table assumes appropriate application of the technology being considered.

Note: For log scaling purposes set zero to equal E-12 (i.e., $1 \times 10^{-12}$ ). 
Table 2.10. Arid Site Guidance Table for Estimating Default HC Factors (Log Scale)

Arid Site Guidance Table for Estimating HC Factors (Log Scale)

Pathway: Air (Use in conjunction with Soil $=>G W=>S W$ factors when considering actions that remove material from Air to Soil $=>G W=>S W$ Pathways

\begin{tabular}{|c|c|c|c|c|c|c|}
\hline \multirow[b]{2}{*}{ Risk Reduction Activity } & \multicolumn{3}{|c|}{ High Mobility } & \multicolumn{3}{|c|}{ Low Mobility } \\
\hline & $\begin{array}{l}\text { Organic } \\
\text { (no or long } \\
\left.\text { Bio. } \mathrm{T}_{1 / 2}\right)\end{array}$ & \begin{tabular}{|c|} 
Inorganic or \\
Long $\mathrm{T}_{1 / 2}$ \\
Rad.
\end{tabular} & $\begin{array}{c}\text { Short } \mathrm{T}_{1 / 2} \\
\text { Rad }\end{array}$ & $\begin{array}{c}\text { Organic } \\
\text { (no or long } \\
\text { Bio. } \mathrm{T}_{1 / 2} \text { ) }\end{array}$ & \begin{tabular}{c|} 
Inorganic \\
or Long \\
$\mathrm{T}_{1 / 2} \mathrm{Rad}$ \\
\end{tabular} & $\begin{array}{c}\text { Short } \mathrm{T}_{1 / 2} \\
\operatorname{Rad}\end{array}$ \\
\hline Retrieval w/Sludge/Soil Washing & \multicolumn{6}{|c|}{$\begin{array}{l}\text { Specific contaminant quantity decrease by washing efficiency fraction }(\mathrm{Qc} * \\
\text { Removal Fraction) } \mathrm{HCc}=\text { Removal Fraction }\end{array}$} \\
\hline Retrieval w/Contaminant Separation & \multicolumn{6}{|c|}{$\begin{array}{l}\text { Specific Contaminant quantity decrease of separated contaminants }(\mathrm{Qc} * \\
\text { Separation Fraction) } \mathrm{HCc}=\text { Separation Fraction }\end{array}$} \\
\hline Vitrification to Offsite & E-12 & E-12 & E-12 & E-12 & E-12 & $\mathrm{E}-12$ \\
\hline Vitrification to Onsite & E-12 & E-12 & E-12 & E-12 & E-12 & E-12 \\
\hline Cemented Solidification & E-9 & E-9 & E-9 & E-9 & E-9 & E-9 \\
\hline $\begin{array}{l}\text { Liquid to Solid Stabilization } \\
\text { (solidification) }\end{array}$ & E-9 & E-9 & E-9 & E-9 & E-9 & E-9 \\
\hline Chemically Immobilize & $E-1$ & E-1 & E-3 & 1 & 1 & E-2 \\
\hline $\begin{array}{l}\text { Water Removal from Wet Storage } \\
\text { Facilities }\end{array}$ & E-1 & E-2 & E-4 & E-1 & E-1 & E-4 \\
\hline Safe Store to Allow Decay to Offsite & \multicolumn{6}{|c|}{$\begin{array}{l}\text { Quantity Decrease (1-Fraction of Contaminant Inventory Eliminated) (Q } \\
\text { decreased) } \mathrm{W} / \mathrm{HC}=1\end{array}$} \\
\hline Thermal Stabilization & 1 & \begin{tabular}{|r|}
1 \\
\end{tabular} & 1 & 1 & 1 & \\
\hline Macroencapsulation & E-12 & E-12 & E-12 & E-12 & E-12 & E-12 \\
\hline Amalgamation (e.g., Hg) & E-12 & E-12 & E-12 & & & \\
\hline $\begin{array}{l}\text { Removal from Pathway } \\
\text { Repackaging/Containerization for } \\
\text { Disposal Onsite }\end{array}$ & \multicolumn{6}{|c|}{$\begin{array}{l}\text { Volume Decrease (1-Fract. Contaminant Inv. Elim.*Disposal Multiplier) } \\
\text { Note: Don't foprget to add the quantity removed from this pathway to the new } \\
\text { pathway }\end{array}$} \\
\hline Disposal/Bury W/O Cap & E-12 & \begin{tabular}{|r|}
$\mathrm{E}-12$ \\
\end{tabular} & E-12 & E-12 & E-12 & E-12 \\
\hline Disposal/Bury W/ HI Cap & E-12 & E-12 & E-12 & E-12 & E-12 & E-12 \\
\hline $\begin{array}{l}\text { Removal from Pathway } \\
\text { Repackaging/Containerization for } \\
\text { Disposal Offsite }\end{array}$ & \multicolumn{6}{|c|}{$\begin{array}{l}\text { Quantity Decreased (Multiply by Fraction of Contaminant Quantity } \\
\text { Eliminated) }\end{array}$} \\
\hline $\begin{array}{l}\text { Increase Transport Time to Receptor } \\
\text { (that is, move away from population or } \\
\text { env. of concern) }\end{array}$ & $\mathrm{E}-1$ to $\mathrm{E}-3$ & $\mathrm{E}-1$ to $\mathrm{E}-3$ & E-1 to E-3 & E-1 to E3 & E-1 to E-3 & E-1 to E-3 \\
\hline Pu Stabilization & E-6 & E-6 & E-6 & E-6 & E-6 & E-6 \\
\hline Packaging W/ Geologic Disposal & E-12 & E-12 & $\mathrm{E}-12$ & E-12 & E-12 & E-12 \\
\hline Packaging W/ WIPP Disposal (Offsite) & E-12 & E-12 & E-12 & E-12 & E-12 & E-12 \\
\hline Incineration & E-12 & \begin{tabular}{r|}
1 \\
\end{tabular} & 1 & E-12 & 1 & \\
\hline Equipment/Facility/Area D\&D & \multicolumn{6}{|c|}{ Quantity Decreased (Fraction of Contaminant Inventory Eliminated) } \\
\hline Disposal RCRA Facility Offsite & E-12 & E-12 & $\mathrm{E}-12$ & E-12 & E-12 & E-12 \\
\hline
\end{tabular}

Note: Do not consider these estimated HC values as "hard and fast" values, feel free to adjust as appropriate. This table is only meant to provide guidance on estimating $\mathrm{HC}$ factors. Best scientific judgment should be considered when assigning $\mathrm{HC}$ values. For example, consider the degree and thoroughness of the control application. In the case of increasing transport time to receptor, consider the distance and conditions of normal transport when picking an HC value to represent moving a source away from the receptor(s). Maintaining consistency in assigning HC values is very important.

Note: Table assumes appropriate application of the technology being considered.

Note: For log scaling purposes set zero to equal E-12(i.e., $1 \times 10^{-12}$ ). 
Table 2.11. Humid Site Guidance Table for Estimating Default HC Factors (Log Scale)

\begin{tabular}{|c|c|c|c|c|c|c|}
\hline \multicolumn{4}{|c|}{ Humid Site Guidance Table for Es timating HC Factors (Log Scale) } & \multicolumn{3}{|c|}{$\begin{array}{l}\text { Pathway: Air (Use in conjunction with Soil }=>G W=>S W \text { factors when considering actions that remove material from Air } \\
\text { to Soil }=>G W=>S W \text { Pathways }\end{array}$} \\
\hline \multirow[b]{2}{*}{ Risk Reduction Activity } & \multicolumn{3}{|c|}{\begin{tabular}{|c|} 
High Mobility \\
\end{tabular}} & \multicolumn{3}{|c|}{$\begin{array}{c}\text { Low Mobility } \\
\end{array}$} \\
\hline & $\begin{array}{l}\text { Organic } \\
\text { (no or long } \\
\text { B io. } \mathrm{T}_{1 / 2} \text { ) }\end{array}$ & $\begin{array}{c}\text { Inorganic } \\
\text { or Long } \\
\mathrm{T}_{1 / 2} \mathrm{Rad}\end{array}$ & $\begin{array}{c}\text { Short } \mathrm{T}_{1 / 2} \\
\mathrm{Rad}\end{array}$ & $\begin{array}{l}\text { Organic } \\
\text { (no or long } \\
\text { B io. } \mathrm{T}_{1 / 2} \text { ) }\end{array}$ & $\begin{array}{c}\text { Inorganic } \\
\text { or Long } \\
\mathrm{T}_{1 / 2} \text { Rad }\end{array}$ & $\begin{array}{l}\text { Short } \mathrm{T}_{1 / 2} \\
\text { Rad }\end{array}$ \\
\hline Retrievalw/Sludge/Soil W ashing & \multicolumn{6}{|c|}{$\begin{array}{l}\text { Specific contaminant quantity decrease by washing efficiency fraction (Qc } \\
* \text { Removal Fraction) } \mathrm{HCc}=\text { Removal Fraction }\end{array}$} \\
\hline Retrievalw/Contaminant Separation & \multicolumn{6}{|c|}{$\begin{array}{l}\text { Specific contaminant decrease of separated contaminants }(\mathrm{Q} c * \text { Separation } \\
\text { Fraction }) \mathrm{HCc}=\text { Separation Fraction }\end{array}$} \\
\hline Vitrification to $\mathrm{O}$ ffsite & E-12 & $\mathrm{E}-12$ & E-12 & E-12 & $\mathrm{E}-12$ & $\mathrm{E}-12$ \\
\hline Vitrification to Onsite & E-12 & E-12 & E-12 & E-12 & E-12 & E-12 \\
\hline Cemented Solidification & E-9 & E-9 & E-9 & E-9 & E-9 & E-9 \\
\hline $\begin{array}{l}\text { Liquid to Solid Stabilization } \\
\text { (solidification) }\end{array}$ & E-9 & E-9 & E-9 & E-9 & E-9 & E-9 \\
\hline Chemic a lly Immobilize & E-1 & E-1 & $E-3$ & 1 & 1 & E-2 \\
\hline $\begin{array}{l}\text { W ater Removal from Wet Storage } \\
\text { Facilities }\end{array}$ & $\mathrm{E}-1$ & $\mathrm{E}-2$ & E-4 & E-1 & E-1 & E-4 \\
\hline Safe Store to Allow Decay to Offsite & \multicolumn{6}{|c|}{$\begin{array}{l}\text { Quantity Decrease (1-Fraction of Contaminant Inventory Eliminated) (Q } \\
\text { decreased) } \mathrm{W} / \mathrm{HC}=1\end{array}$} \\
\hline \begin{tabular}{|l|} 
Thermal Stabilization \\
\end{tabular} & 1 & 1 & $\begin{array}{r}1 \\
\end{array}$ & \begin{tabular}{r|}
1 \\
\end{tabular} & 1 & $\begin{array}{ll} \\
\end{array}$ \\
\hline Macroencapsulation & $\mathrm{E}-12$ & $\mathrm{E}-12$ & $\mathrm{E}-12$ & $\mathrm{E}-12$ & E-12 & E-12 \\
\hline A malgamation (e.g., Hg) & $\mathrm{E}-12$ & $\mathrm{E}-12$ & E-12 & & & \\
\hline $\begin{array}{l}\text { Removal from Pathway } \\
\text { Repackaging/Containerization for } \\
\text { D isposal Onsite }\end{array}$ & \multicolumn{6}{|c|}{$\begin{array}{l}\text { Volume Decrease (1-Fract. Contaminant Inv. Elim. }{ }^{*} \text { Disposal Multiplier) } \\
\text { Note: Don't forget to add the quantity removed from this pathway to the } \\
\text { new pathway }\end{array}$} \\
\hline D isposal/Bury W/O Cap & \begin{tabular}{|r|}
$E-12$ \\
\end{tabular} & $\mathrm{E}-12$ & E-12 & \begin{tabular}{|r|}
$\mathrm{E}-12$ \\
\end{tabular} & $\mathrm{E}-12$ & E-12 \\
\hline D isposal/Bury W/ H I Cap & E-12 & $\mathrm{E}-12$ & $\mathrm{E}-12$ & $E-12$ & E-12 & E-12 \\
\hline \begin{tabular}{|l|} 
Removal from Pathway \\
Repackaging/Containerization for \\
Disposal Offsite
\end{tabular} & \multicolumn{6}{|c|}{$\begin{array}{l}\text { Quantity Decreased (Multiply by Fraction of Contaminant Quantity } \\
\text { Eliminated) }\end{array}$} \\
\hline $\begin{array}{l}\text { Increase Transport Time to Receptor } \\
\text { (that is, move away from population } \\
\text { or env. of concern) }\end{array}$ & $\mathrm{E}-1$ to $\mathrm{E}-3$ & $\mathrm{E}-1$ to $\mathrm{E}-3$ & $\mathrm{E}-1$ to $\mathrm{E}-3$ & E-1 to E3 & $\mathrm{E}-1$ to $\mathrm{E}-3$ & $\mathrm{E}-1$ to $\mathrm{E}-3$ \\
\hline $\mathrm{Pu}$ Stabilization & E-6 & E-6 & E-6 & E-6 & E-6 & E-6 \\
\hline Packaging W/Geologic D isposal & $\mathrm{E}-12$ & $\mathrm{E}-12$ & $\mathrm{E}-12$ & $\mathrm{E}-12$ & E-12 & E-12 \\
\hline $\begin{array}{l}\text { Packaging W/ W IP P D isposal } \\
\text { (Offsite) }\end{array}$ & E-12 & E-12 & E-12 & $\mathrm{E}-12$ & E-12 & $\mathrm{E}-12$ \\
\hline Incineration & \begin{tabular}{|r|}
$E-12$ \\
\end{tabular} & 1 & $\begin{array}{r}1 \\
\end{array}$ & \begin{tabular}{|r|}
$\mathrm{E}-12$ \\
\end{tabular} & 1 & \\
\hline Equipment/Facility/Area D \& D & \multicolumn{6}{|c|}{ Quantity Decreased (Fraction of Contaminant Inventory Eliminated) } \\
\hline Disposal RCRA Facility Offsite & E-12 & $\mathrm{E}-12$ & $\begin{array}{r}\mathrm{E}-12 \\
\end{array}$ & \begin{tabular}{|r|}
$\mathrm{E}-12$ \\
\end{tabular} & $\mathrm{E}-12$ & E-12 \\
\hline
\end{tabular}

Note: Do not consider these estimated HC values as "hard and fast" values, feel free to adjust as appropriate. This table is only meant to provide guidance on estimating HC factors. Best scientific judgment should be considered when assigning $\mathrm{HC}$ values. For example, consider the degree and thoroughness of the control application. In the case of increasing transport time to receptor, consider the distance and conditions of normal transport when picking an HC value to represent moving a source away from the receptor(s). Maintaining consistency in assigning $\mathrm{HC}$ values is very important.

Note: Table assumes appropriate application of the technology being considered.

Note: For log scaling purposes set zero to equal E-12 (i.e., $1 \times 10^{-12}$ ). 



\subsection{Risk Measure Calculation}

The relative hazard factor tracks the change in hazard over time. Another important consideration is the change in risk for the facility. As mentioned previously, the relative risk is related to the relative hazard by the frequency of a release event for the facility. A risk measure (RM) can be calculated in a manner similar to the relative hazard factor by addition of the hazard likelihood (HL) to the relative hazard equation. The hazard likelihood is represented as the expected frequency of the event that results in release of a contaminant to the environment.

The original equation for evaluating RM at a specific time (year end) was as follows:

$$
R M=\frac{\sum_{c c=1}^{n} H L c c t Q_{c c t} R F_{c c c t} H M_{c c t} H C_{c c t}}{\sum_{c c=1}^{n} Q_{c c t 0} R F_{c c c t 0} H M_{c c t 0} H C_{c c t 0}}
$$

where $\quad \mathrm{RM}=$ risk measure at time $\mathrm{t}$ (per year)

$\mathrm{HL}_{\mathrm{cct}}=$ likelihood that a release will occur for the controlling constituents at time $\mathrm{t}$ (i.e., time when specified mitigation, cleanup, or risk management action is completed)

$\mathrm{Q}_{\mathrm{cct}}=$ quantity of the controlling constituents (radionuclides, in curies and hazardous chemicals, in kilograms) at time t (i.e., time when specified risk management action is completed)

$\mathrm{Q}_{\text {cct0 }}=$ quantity of the controlling constituents (radionuclides, in curies and hazardous chemicals, in kilograms) at time t0 (i.e., the original baseline or starting time)

$\mathrm{RF}_{\mathrm{cct}}=$ fraction of the controlling constituent quantity that is releasable to the controlling pathway at time $t$

$\mathrm{RF}_{\text {cct0 }}=$ fraction of the controlling constituent quantity that is releasable to the controlling pathway at time t0

$\mathrm{HM}_{\mathrm{cct}}=$ hazard measure factor for controlling constituent and controlling pathway at time $t$ (hazard measure factors from look-up tables)

$\mathrm{HM}_{\mathrm{cct} 0}=$ hazard measure factor for controlling constituent and controlling pathway at time t0 (hazard measure factors from look-up tables)

$\mathrm{HC}_{\mathrm{cct}}=$ hazard control factor for risk management control action specific at time $\mathrm{t}$ (hazard control factors may be estimated from site risk data or approximated using supplied look-up tables)

$\mathrm{HC}_{\text {cct0 }}=$ hazard control factor for risk management control action specific at time t0 (hazard control factors may be estimated from site risk data or approximated using supplied look-up tables)

$\mathrm{n}=$ number of controlling constituents.

The original equation was written with time as a general parameter. The original approach necessitated implementation to be limited to 1-year time periods so results could only be presented on an annual basis, 
which was fine for the original hazard and risk profile purposes. However, expanded management applications of the methodology necessitates accounting for specific material-state time periods. Thus, the RM equation was modified to explicitly represent each material state involved in each year of the analysis. An additional parameter was added to the numerator of the equation to account for the fraction of a year that the material is in each state. If the assumption is made in an application that the initial condition involves only storage of material in the initial state, for example, then the time factors will simply be unity.

The original equation was based on the hazardous material being represented as an analyte (e.g. $\left.{ }^{239} \mathrm{Pu}\right)$. The revised equation is based on material states with the analyte as a sub-component of the material. The revised RM (and RH) equation includes the following parameterizations:

Time: each evaluation is performed for a one year period, with the results applied at the end of the year.

Material state: all material states involved in the current year are analyzed. The fraction of the year that a material is in each state must be defined.

Analyte: each material is composed of one or more hazardous analytes. These analytes determine the nature of the hazard associated with the material. The hazard measure (HM) values are based on the analyte properties.

The revised RM equation includes the summation over material types as shown in the equation below. In the revised equation the original subscript for contaminant of concern (cc) has been simplified to one letter (c) and a new index for material "m" has been added.

$$
R M=\frac{\sum_{c c=1}^{n} \sum_{m=1}^{M} H L_{c m t} F_{m t} Q_{c m t} R F_{c m t} H M_{c t} H C_{c m t}}{\sum_{c=1}^{n} \sum_{m=1}^{M} F_{m 0} Q_{c m t 0} R F_{c m t 0} H M_{c t 0} H C_{c m t 0}}
$$

where $\quad \mathrm{HL}_{\mathrm{cmt}}=$ likelihood that a release will occur for the controlling constituent $\mathrm{c}$ for material state $\mathrm{m}$, at time $\mathrm{t}$

$\mathrm{Q}_{\mathrm{cmt}}=$ quantity of the controlling constituent (radionuclides, in curies and hazardous chemicals, in kilograms) for material state $m$, at time $t$ (i.e., time when specified risk management action is completed)

$\mathrm{Q}_{\mathrm{cmt} 0}=$ quantity of the controlling constituent (radionuclides, in curiesand hazardous chemicals, in kilograms) in material state $\mathrm{m}$, at time t0 (i.e., the original baseline or starting time)

$\mathrm{F}_{\mathrm{mt}}=$ fraction of time that the material is in state $\mathrm{m}$ during time $\mathrm{t}$

$\mathrm{F}_{\mathrm{m} 0}=$ fraction of time that the material is in state $\mathrm{m}$ at the initial time.

$\mathrm{RF}_{\mathrm{cmt}}=$ fraction of controlling constituent quantity in material state $\mathrm{m}$, that is releasable to the controlling pathway at time $t$

$\mathrm{RF}_{\mathrm{cmt} 0}=$ fraction of the controlling constituent quantity in material state $\mathrm{m}$, that is releasable to the controlling pathway at time t0 

$\mathrm{HM}_{\mathrm{c}}=$ hazard measure factor for controlling constituent and controlling pathway at time $\mathrm{t}$ (hazard measure factors from look-up tables)
$\mathrm{HM}_{\mathrm{ct} 0}=$ hazard measure factor for controlling constituent and controlling pathway at time t0 (hazard measure factors from look-up tables)
$\mathrm{HC}_{\mathrm{cmt}}=$ hazard control factor for risk management control action specific at time $\mathrm{t}$ for material state $\mathrm{m}$ (hazard control factors may be estimated from site risk data or approximated using supplied look-up tables)
$\mathrm{HC}_{\mathrm{cmt} 0}=$ hazard control factor for risk management control action specific at time to for material state $\mathrm{m}$ (hazard control factors may be estimated from site risk data or approximated using supplied look-up tables)
$\mathrm{M}=$ number of material states
$\mathrm{n} \quad=$ number of controlling constituents.

In the revised equation, the new summation is over material states. For the base case (time zero), only those states that are initially present (e.g., storage states) are included in the analysis because the time factors, $\mathrm{F}_{\mathrm{m} 0}$, for other states are zero. The initial time factors for the included states, $\mathrm{F}_{\mathrm{m} 0}$, are assigned a value of 1.0. Another change has been to add dependence on material state to the HC parameters because the location of the material can influence the $\mathrm{HC}$ factor.

\section{Implementation changes}

Implementation of the original RH and RM equations involved reading PROCESS keywords defining actions taken that change the state of materials. The initial and final states were defined, and then the fraction of the initial state that changed was given, followed by the duration over which the change occurs. The assumption was made that the change occurred uniformly over the time period. The times were in multiples of 1 year. This representation was updated to account for processing to occur within one year, so that the final state (e.g., a second storage state) and all intermediate processing states are included in the analysis during the current year.

The following is an example of the kinds of one year of disposition activity that involves processing.

Initial state: Storage in a vault, state 1.

Processes: $\quad$ Removal from vault and transfer to processing cell. Processing of material to stable state in processing cell, state 2 . Transfer of material from processing cell to final storage location in stable state.

Final state: $\quad$ Storage of stable state in new storage configuration.

The analysis must include the fraction of the year that the material is in each storage state and the fraction of the year that the material is out of storage for processing. The above example shows three material states. The numerator of the RM equation for this example can be written as follows for analyte $\mathrm{c}$ and time period $\mathrm{t}$ :

$\mathrm{RM}$ (numerator) $=\left(\mathrm{HL}_{\mathrm{c} 1 \mathrm{t}} \mathrm{Q}_{\mathrm{c} 1 \mathrm{t}} \mathrm{F}_{1 \mathrm{t}} \mathrm{RF}_{\mathrm{clt}} \mathrm{HC}_{\mathrm{c} 1 \mathrm{t}}+\mathrm{HL}_{\mathrm{c} 2 \mathrm{Q}} \mathrm{Q}_{\mathrm{c} 2 \mathrm{t}} \mathrm{F}_{2 \mathrm{t}} \mathrm{RF}_{\mathrm{c} 2 \mathrm{t}} \mathrm{HC}_{\mathrm{c} 2 \mathrm{t}}+\mathrm{HL}_{\mathrm{c} 3 \mathrm{t}} \mathrm{Q}_{\mathrm{c} 3 \mathrm{t}} \mathrm{F}_{3 \mathrm{t}} \mathrm{RF}_{\mathrm{c} 3 \mathrm{t}} \mathrm{HC}_{\mathrm{c} 3 \mathrm{t}}\right) \mathrm{HM}_{\mathrm{ct}}$ 
$\mathrm{F}_{1 \mathrm{t}}+\mathrm{F}_{2 \mathrm{t}}+\mathrm{F}_{3 \mathrm{t}} \leq 1.0$

It should be noted, that the sum of time fractions could be less than one if material is transported offsite and the analysis is only to include consideration of onsite material.

The RM associated with the processing operation (material state 2 in the above example) would be assigned to the entire time period out of storage. This should be a reasonable assumption because materials are usually kept in storage when not being processed.

The RHRM FORTRAN code was revised to implement the revised equation to better represent the processing of material as a function of time as it goes through the various material states.

Initial material states are required for evaluation of the denominator in the RM equation. No processing is involved in the initial material states. In the RHRM code, processing is represented using the PROCESS keyword records read from the processing keyword file. Each PROCESS keyword record defines an initial and final state, the time period of processing, and the fraction of the initial material that is processed during the time period. The final state represents the material state while being processed. A subsequent PROECSS keyword record is required to move the material from the processing state to the next material storage state. This representation has resulted in the need to do significant prior analyses to determine the correct representation and processing fractions for each PROCESS keyword record. The goal of the current revision is to develop a simpler method to represent the changes in material state with time so prior analyses are not necessary.

In the RHRM code, the SCOPE keyword record is used to define all material states to be included in the analysis and the amount of material initially present in the material states. The amount on the SCOPE record is the total $\mathrm{kg}$ of material. The concentration of each analyte in the material is defined on MATERIAL keyword records. For example, the MATERIAL keyword record will provide the $\mathrm{Ci} / \mathrm{kg}$ of each radionuclide in the material.

\section{Relation of RHRM code parameters to the RM equation}

The quantity of an analyte in a material state at time $t\left(\mathrm{Q}_{\mathrm{cmt}}\right)$ is represented as the product of the amount of material present in the material state in time period $t$ ( 1 calendar year) and the concentration of the analyte in the material, with correction for decay as necessary. The relative hazard considers this quantity of material and the time $\left(\mathrm{F}_{\mathrm{mt}}\right)$ it is within each state during the year. The product of $\mathrm{Q}_{\mathrm{cmt}}$ and $\mathrm{F}_{\mathrm{mt}}$ is the basis for determining the relative hazard during period $\mathrm{t}$ for material $\mathrm{m}$ and analyte $\mathrm{c}$, as indicated in the above example.

The amount of material present in the material state is not explicitly represented in the RM equation, but must be determined in the RHRM code implementation of the equation. This is the basis for the change in RM with time. The initial material present (time zero) is provided in the SCOPE keyword records. 


\section{Revised Processing Algorithm}

A revised processing algorithm was developed for the RHRM code to better represent the time change of material in each material state. This was necessary to implement the change in the RM equation described above where the time fraction parameter, $\mathrm{F}_{\mathrm{mt}}$, has been added to the analysis.

Most of these terms (other than the hazard likelihood) are defined and evaluated the same as for the RH evaluation described in Section 2. These terms are not addressed in this section. Note that the hazard likelihood (HL) is only added to the numerator of the relative hazard equation. This allows the risk measure to be compared to the relative hazard values and plotted as a function of time.

\subsection{Hazard Likelihood Factor}

The hazard likelihood (HL) factor is related to the frequency of an event that results in release of material or otherwise results in impacts to the public or workers. Guidance is given in this section on evaluation of the event frequencies.

The HL factor represents the likelihood (or frequency) that a release will occur for a controlling event and for the controlling constituent. This factor can be thought of as the probability or frequency of a specific accident that results in a release. The frequency is usually expressed on an annual basis (e.g., events/year). The frequency is defined for the event that is most likely to release the controlling constituent in the largest amount. When there are multiple events postulated that release the controlling constituent, the analysis may need to include more that one event. In cases where actions are defined to reduce the RM, the analyst should be aware of alternate events that may become dominant when the initially dominant event is mitigated by protective actions that do not mitigate the alternative event frequencies.

The assignment of accident frequencies must be based on knowledge of the facility and processes. This may include the use of knowledgeable staff in assigning frequencies, or reliance on safety analysis reports or other similar reports for the facility. The risk assessment handbook for Rocky Flats safety analysis (RFETS 1997) describes a method for performing safety analysis for nuclear facilities at Rocky Flats. The handbook describes a methodological approach to assess the potential hazards for a facility and prepare necessary documentation of the risks. The method relies on use of staff familiar with the facility and processes. The Rocky Flats handbook provides a table of frequency bin designations for use in accident analyses. These designations are listed in Table 3.1 with suggested midrange values.

Table 3.1. Suggested Frequency Bin Designations

\begin{tabular}{|l|l|l|}
\hline Frequency Category & $\begin{array}{l}\text { Frequency Range } \\
\text { (events/year) }\end{array}$ & $\begin{array}{l}\text { Midrange Value } \\
\text { (events/year) }\end{array}$ \\
\hline Normal operations & $>1.0$ & 1.0 \\
\hline Expected or anticipated & 0.01 to 1.0 & 0.1 \\
\hline Unlikely & $1 \mathrm{E}-4$ to $1 \mathrm{E}-2$ & $1 \mathrm{E}-3$ \\
\hline Extremely unlikely & $1 \mathrm{E}-6$ to $1 \mathrm{E}-4$ & $1 \mathrm{E}-5$ \\
\hline Incredible & $<1 \mathrm{E}-6$ & $1 \mathrm{E}-7$ \\
\hline
\end{tabular}

In the past few years, the DOE has investigated the state of the DOE complex holdings of spent fuel, chemicals, plutonium, and highly-enriched uranium in an attempt to identify materials and conditions that pose a threat to health and safety for workers or the public. The plutonium vulnerability study (DOE 
1994) and the highly-enriched uranium vulnerability study (DOE 1996) both employed a simplified consequence analysis method to estimate the potential for adverse health impacts. This analysis method was applied to each vulnerability identified for each DOE site and facility included in the study.

Vulnerabilities were classified according to type, likelihood, and consequences. The vulnerability type classification was either material packaging (MP), facility condition (FC), or institutional (IV). These classifications are intended to indicate the primary cause for the vulnerability. Material packaging classification is used for vulnerabilities that involve susceptibility of materials and packaging to degradation from design deficiencies, corrosion, radiolytic damage, or changes in chemical form. Facility condition classification is used for vulnerabilities involving potential for failure of physical barriers such as equipment, building, or safety systems, and the hold-up of plutonium or uranium in a facility (e.g. ductwork). Institutional vulnerabilities involve administrative or management weaknesses that are underlying causes of or significant contributors to, material/packaging and facility condition vulnerabilities. The likelihood categories employed in each of these studies are indicated in Table 3.2.

Table 3.2. Likelihood Categories used in the Vulnerability Studies

\begin{tabular}{|c|c|c|}
\hline Category & $\begin{array}{c}\text { HEU Vulnerability } \\
\text { Study }\end{array}$ & $\begin{array}{c}\text { Pu Vulnerability } \\
\text { Study }\end{array}$ \\
\hline Very Low & $\begin{array}{c}<0.02, \text { less than once in } \\
50 \text { years }\end{array}$ & $\begin{array}{c}\text { very small frequency } \\
\text { expected }\end{array}$ \\
\hline Low & $\begin{array}{c}0.02-0.2 \text {, once in } 5-50 \\
\text { years }\end{array}$ & $\begin{array}{c}0.02-0.2, \text { once in } 5- \\
50 \text { years }\end{array}$ \\
\hline Medium & - & $\begin{array}{c}0.2-0.5, \text { once in } 2-5 \\
\text { years }\end{array}$ \\
\hline High & $>0.2$, within 5 years & $>0.5$, within 2 years \\
\hline
\end{tabular}

The very low category was typically applied to events resulting from natural phenomena (e.g., seismic events) and is consistent with the incredible to unlikely categories given in Table 3.1. The low and medium categories are within the expected or anticipated categories. The high approaches the normal operations range. The vulnerability studies were primarily interested in the problems most likely to occur and cause health or environmental impacts.

The vulnerability summary tables for these studies have been reviewed and the vulnerabilities have been grouped by cause, event, and likelihood in Table 3.3 and 3.4 for the plutonium and highly-enriched uranium studies, respectively. The tables include most vulnerabilities, but exclude the institutional vulnerabilities which were not assigned frequency categories by the vulnerability studies.

A few generalizations can be made from the information in these tables. Events resulting from human error are in the "expected or anticipated" frequency category. Poor packaging of plutonium or uranium is likely to result in "expected or anticipated" frequency category events. Seismic events are related to the "unlikely" category. Events involving contamination (rooms, ducts, equipment, etc.) are in the "expected or anticipated" frequency category.

Table 3.3. Likelihood Summary for Plutonium Vulnerability Study

\begin{tabular}{|c|c|c|c|c|c|}
\hline \multirow{2}{*}{ Cause } & \multirow{4}{*}{ Event } & \multicolumn{4}{|c|}{ Likelihood Category } \\
\cline { 3 - 5 } & & VL & L & M & H \\
& & $<<0.02$ & $0.02-$ & $0.2-0.5$ & $>0.5$ \\
& & & 0.2 & & \\
\hline
\end{tabular}




\begin{tabular}{|c|c|c|c|c|c|}
\hline & & \multicolumn{4}{|c|}{ Number of Vulnerabilities } \\
\hline \multirow{4}{*}{$\begin{array}{l}\text { human error or } \\
\text { equipment failure }\end{array}$} & building fire & - & 7 & 1 & - \\
\hline & breach of facility & - & 9 & 12 & 10 \\
\hline & criticality & - & 3 & 1 & - \\
\hline & worker exposure & - & 2 & 2 & - \\
\hline $\begin{array}{l}\text { long-term plutonium } \\
\text { solution storage in } \\
\text { plastic bottles }\end{array}$ & leakage/spill & - & - & - & 7 \\
\hline \multirow{3}{*}{$\begin{array}{l}\text { material package } \\
\text { physical condition }\end{array}$} & container breach & - & 10 & 10 & 18 \\
\hline & material fire & - & - & 1 & 6 \\
\hline & solution spill & - & 1 & 2 & 1 \\
\hline $\begin{array}{l}\text { plutonium metal or } \\
\text { oxides stored in } \\
\text { contact with plastic or } \\
\text { oxidation }\end{array}$ & container breach & - & 9 & 5 & 1 \\
\hline \multirow[t]{2}{*}{ internal explosion } & release inside building & - & 2 & - & - \\
\hline & breach of facility & - & 7 & - & - \\
\hline $\begin{array}{l}\text { inadequacy of } \\
\text { criticality safety limits }\end{array}$ & criticality & - & 5 & - & - \\
\hline \multirow[t]{3}{*}{ seismic event } & criticality & 1 & 4 & - & - \\
\hline & material fire & 1 & 1 & - & - \\
\hline & breach of facility & 16 & - & - & - \\
\hline aircraft crash & breach of facility & 1 & 3 & - & - \\
\hline extreme winds & breach of facility & 1 & - & - & - \\
\hline $\begin{array}{l}\text { contaminated rooms } \\
\text { or equipment }\end{array}$ & release & - & 14 & 4 & 11 \\
\hline $\begin{array}{l}\text { unnecessary } \\
\text { combustible material }\end{array}$ & fire or explosions & - & 3 & 1 & - \\
\hline
\end{tabular}


Table 3.4. Likelihood Summary for the Highly-Enriched Uranium Vulnerability Study

\begin{tabular}{|c|c|c|c|c|}
\hline \multirow[b]{3}{*}{ Cause } & \multirow[b]{3}{*}{ Event } & \multicolumn{3}{|c|}{ Likelihood Category } \\
\hline & & $\begin{array}{c}\mathrm{VL} \\
<<0.02\end{array}$ & $\begin{array}{c}L \\
0.02- \\
0.2\end{array}$ & $\begin{array}{c}\mathrm{H} \\
>0.2\end{array}$ \\
\hline & & \multicolumn{3}{|c|}{ Number of Vulnerabilities } \\
\hline \multirow{3}{*}{$\begin{array}{l}\text { human error or } \\
\text { equipment failure }\end{array}$} & building fire & - & 3 & - \\
\hline & breach of facility & 3 & 1 & 4 \\
\hline & worker exposure & - & 2 & 2 \\
\hline \multirow[t]{4}{*}{ facility deficiency } & release & 4 & 5 & 6 \\
\hline & criticality & 1 & 2 & - \\
\hline & worker exposure & - & 1 & 1 \\
\hline & fire & - & 3 & - \\
\hline \multirow{4}{*}{$\begin{array}{l}\text { inadequate storage, } \\
\text { material package } \\
\text { physical condition }\end{array}$} & container breach & - & 5 & 6 \\
\hline & criticality & 1 & 4 & - \\
\hline & worker exposure & - & 2 & 1 \\
\hline & solution spill & - & 1 & - \\
\hline $\begin{array}{l}\text { HEU with plutonium } \\
\text { in contact with plastic }\end{array}$ & release & - & 1 & - \\
\hline $\begin{array}{l}\text { pyrophoric metal chip } \\
\text { storage }\end{array}$ & fire & 3 & 3 & - \\
\hline $\begin{array}{l}\text { chemical reaction, } \\
\text { explosion }\end{array}$ & breach of facility & 1 & 3 & - \\
\hline \multirow[t]{3}{*}{ seismic event } & criticality & 3 & - & - \\
\hline & spill & 1 & - & - \\
\hline & breach of facility & 10 & 1 & - \\
\hline winds & breach of facility & 4 & 1 & - \\
\hline $\begin{array}{l}\text { transportation } \\
\text { accident }\end{array}$ & release & 1 & 1 & - \\
\hline \multirow{3}{*}{$\begin{array}{l}\text { holdup in process } \\
\text { equipment or ducts }\end{array}$} & breach of facility & - & 1 & 1 \\
\hline & fire & 1 & - & - \\
\hline & criticality & - & 11 & - \\
\hline $\begin{array}{l}\text { contaminated rooms } \\
\text { or equipment }\end{array}$ & release & - & - & 1 \\
\hline $\begin{array}{l}\text { unnecessary } \\
\text { combustible material }\end{array}$ & fire or explosions & 2 & 7 & 3 \\
\hline
\end{tabular}

\subsection{Reductions in Hazard Likelihood Factor}

Actions taken to reduce the risk from an identified deficiency may result in a reduction in the likelihood of a controlling event. This section provides guidance on evaluating the reduction for representative events.

The reduction in likelihood is very situation specific and should be based on knowledge of the materials, conditions, and the facility in question. The reduction in likelihood should be based on the change in conditions affecting the event that is the cause of the potential release. Suggested ranges for likelihood 
reductions are presented in Table 3.5 for common initiating events or conditions that may contribute to an accident. 
Table 3.5. Suggested Ranges of Likelihood Reductions

\begin{tabular}{|c|c|c|c|c|c|}
\hline $\begin{array}{l}\text { Event of } \\
\text { Concern }\end{array}$ & Mitigation Action & Initial Likelihood & Final Likelihood & $\begin{array}{l}\text { Reduction } \\
\text { Range }\end{array}$ & Comments \\
\hline \multirow[b]{2}{*}{ package failure } & $\begin{array}{l}\text { repackage to safe } \\
\text { form }\end{array}$ & package failure rate & $\begin{array}{l}\text { repackaged failure } \\
\text { rate }\end{array}$ & $0.1-1 \mathrm{E}-6$ & $\begin{array}{l}\text { depends on level of } \\
\text { improvement in packaging }\end{array}$ \\
\hline & $\begin{array}{l}\text { move to facility } \\
\text { with better } \\
\text { confinement }\end{array}$ & package failure rate & $\begin{array}{l}\text { same as initial } \\
\text { likelihood }\end{array}$ & 1.0 & no change in likelihood \\
\hline $\begin{array}{l}\text { facility failure } \\
\text { during seismic } \\
\text { event }\end{array}$ & strengthen facility & $\begin{array}{l}\text { frequency of } \\
\text { minimum } \\
\text { earthquake to cause } \\
\text { failure }\end{array}$ & $\begin{array}{l}\text { frequency of design } \\
\text { earthquake }\end{array}$ & $0.1-1 \mathrm{E}-4$ & $\begin{array}{l}\text { depends on seismic } \\
\text { frequencies for the site }\end{array}$ \\
\hline human error & staff training & $\begin{array}{l}\text { likelihood of human } \\
\text { error for untrained } \\
\text { staff }\end{array}$ & $\begin{array}{l}\text { likelihood of human } \\
\text { error for trained } \\
\text { staff }\end{array}$ & $0.5-0.01$ & $\begin{array}{l}\text { training is likely to reduce } \\
\text { the frequency of human } \\
\text { error events }\end{array}$ \\
\hline \multirow{3}{*}{ facility fire } & $\begin{array}{l}\text { improve facility fire } \\
\text { suppression system }\end{array}$ & $\begin{array}{l}\text { facility fire } \\
\text { frequency without } \\
\text { suppression system }\end{array}$ & $\begin{array}{l}\text { facility fire } \\
\text { frequency with } \\
\text { suppression system }\end{array}$ & $0.1-1 \mathrm{E}-4$ & $\begin{array}{l}\text { improvement in fire } \\
\text { suppression systems will } \\
\text { reduce the likelihood of a } \\
\text { major fire }\end{array}$ \\
\hline & $\begin{array}{l}\text { remove/mitigate fire } \\
\text { initiation conditions }\end{array}$ & $\begin{array}{l}\text { fire likelihood } \\
\text { under initial } \\
\text { conditions }\end{array}$ & $\begin{array}{l}\text { fire likelihood } \\
\text { under mitigated } \\
\text { conditions }\end{array}$ & $0.01-1 \mathrm{E}-6$ & $\begin{array}{l}\text { improving conditions } \\
\text { reduces likelihood of a fire } \\
\text { starting }\end{array}$ \\
\hline & $\begin{array}{l}\text { remove combustible } \\
\text { material }\end{array}$ & $\begin{array}{l}\text { fire likelihood due } \\
\text { to combustible } \\
\text { material }\end{array}$ & $\begin{array}{l}\text { fire likelihood } \\
\text { without } \\
\text { combustible } \\
\text { material }\end{array}$ & $0.1-1 \mathrm{E}-6$ & $\begin{array}{l}\text { removing combustible } \\
\text { materials reduces } \\
\text { likelihood of a fire of } \\
\text { magnitude to cause release }\end{array}$ \\
\hline container breach & $\begin{array}{l}\text { vitrify and store in } \\
\text { solid form }\end{array}$ & $\begin{array}{l}\text { frequency of initial } \\
\text { container breach }\end{array}$ & $\begin{array}{l}\text { frequency of new } \\
\text { container breach }\end{array}$ & $0.5-1 \mathrm{E}-4$ & $\begin{array}{l}\text { depends on container } \\
\text { modifications more than } \\
\text { physical form of material }\end{array}$ \\
\hline criticality & $\begin{array}{l}\text { reconfigure material } \\
\text { or add } \\
\text { administrative } \\
\text { controls }\end{array}$ & $\begin{array}{l}\text { initial criticality } \\
\text { frequency }\end{array}$ & $\begin{array}{l}\text { criticality frequency } \\
\text { after } \\
\text { reconfiguration or } \\
\text { controls }\end{array}$ & $0.1-1 \mathrm{E}-4$ & $\begin{array}{l}\text { reconfiguration to limit } \\
\text { material below critical } \\
\text { mass will reduce } \\
\text { likelihood of criticality }\end{array}$ \\
\hline
\end{tabular}




\subsection{RHRM Methodology Use and Application}

The RHRM methodology is designed to serve as a risk-based environmental management decision tool. Environmental management decisions involve the balancing of costs, schedules, regulatory requirements, and health hazards and risks. The RHRM tools provide the environmental manager the opportunity to predict and track controlling health hazards and risks over time as these hazards and risks change with the performance of mitigation and cleanup actions. These hazards and risks are associated with the technical baseline (i.e., the planned mitigation and cleanup actions). The RHRM tool also provides the environmental manager with the opportunity to explore "what if" scenarios to examine the impact on health hazards and risks for alternative mitigation and cleanup actions (i.e., alternative to the baseline actions).

The output from the RHRM code is designed to produce graphs that enable the environmental manager to easily compare the change in controlling hazards and risks over time with their cost, schedule, and programmatic risk change over time.

In using the RH and RM equations to estimate $\mathrm{RH}$ and $\mathrm{RM}$ ratios and produce relative hazard and risk reduction graphs, one should always apply the test of "technical feasibility and reasonableness" to each factor of the equation and to the final resulting RH and RM value generated over the course of the projected mitigation, cleanup, or risk management actions. In most cases, it will be helpful to either mentally or physically sketch out an intuitive RH and RM graph considering all the risk management actions being considered. Then, once the RH and RM calculations are made, a comparison of the resulting graph with the intuitive graph can be made to test the reasonableness of the results. Any significant discrepancies should be examined closely by looking at the individual parameters and the logic behind them. Such a process will add credibility to situations where unexpected hazard and risk outcomes are discovered through use of the RHRM tool.

The general steps of developing an RH and RM profile include the following (the user interface designed into the RHRM code will lead you through these steps):

- Using site specific current risk/hazard and future risk/hazard management knowledge, action plans, and assessments, determine the controlling constituents, quantities (considering total amounts and releasable fractions of controlling constituents), controlling pathways, and risk management actions pertinent to the waste type being evaluated.

- Assign site specific values for the base case and each risk/hazard management action case to the parameters of the RH and RM equation using data from site specific risk assessments, site specific safety analysis documents, values from look-up tables, and general knowledge of the site in question.

- Assign quantity and release fraction values for the controlling constituents; if all of the quantity is releasable to the controlling pathway(s), the respective release fraction values would be assigned a 1.

- Assign hazard measure values (specific for the controlling constituent and pathway), using the HM look-up tables provided. As the overall risk management approach is examined, consider the logic flow where a specific risk/hazard management activity may cause a change from one pathway to another or a change in the status of the controlling constituent (e.g., a separations and disposal process where the initial controlling constituent is either changed or eliminated, resulting in a different controlling constituent) 
- Assign hazard control values (specific for each risk/hazard management activity). In many cases, the hazard control is simply related to the reduction in the volume (i.e., amount of controlling constituents) of the hazardous material in question. In these cases, simply assign the HC value a 1 and adjust the respective quantity values over time to reflect the reduction or use the FMR or FCR factors, as applicable to generate an $\mathrm{HC}$ value to account for the volume change. The $\mathrm{HC}$ values are intended to reflect significant impact changes in the waste material or its setting (e.g., vitrification of the same amount of waste to change its form, repackaging leaking hazardous material, moving hazardous material away from a vulnerable exposure setting). In some cases, there will be both reduction in volume and changes in the waste material or setting, so a representative $\mathrm{HC}$ value should be used along with a reduction in the respective quantity values (or the appropriate FMR and/or FCR factors of the HC used to account for the volume change). If risk assessment results are available for the general activity or a related activity at the site, use the results of the risk assessment to estimate the order of magnitude worth of the activity. If no pertinent risk assessment results or equivalent data are available, general $\mathrm{HC}$ values are provided in look-up tables to help the user estimate the worth of a specific activity. Use the HC values in combinations with the releasable quantity values and HM parameters to as closely as possible represent the logic flow of all the mitigation, cleanup, or risk management activities at the site.

- The RHRM interface code will assemble all of these RH and RM factor values into an input file for the RHRM code to run. For QA purposes, it would be prudent to document all specific references and assumptions used to generate the input factors. It is suggested that such information be generated in a separate word processor file as the information is being extracted from such references.

- The RHRM code will then calculate the RH and RM values, considering the general flow of mitigation, cleanup, and risk mitigation activities that occur over time. As mentioned, it would be helpful to either mentally or physically sketch out an intuitive graph of the activities over time. These sketches will prove invaluable in selecting the best RH and RM input factors and assure the results are logically reasonable.

- Assign "best estimate" relative time (RT) values based on the general understanding of time associated with the completion of each risk/hazard management activity.

Following an RHRM code run, the system will produce individual waste type RH and RM versus RT (time) plots. These are the RH and RM output profiles, which can be compared with cost, schedule, and programmatic risk versus time plots. 


\subsection{References}

Baggaasen, LM, JL Bryant, JW Buck, J.G. Droppo, B.L. Hoopes, D.L. Strenge, G. Whelan, MK White. 1996. Remedial Action Assessment System (RAAS)) Version 1.1 Electronic Documentation: Technology Module Formulations. PNL-8751, Rev. 3. September 1996. Pacific Northwest National Laboratory, Richland, Washington.

DOE. 1994. Plutonium Working Group Report on Environmental, Safety and Health Vulnerabilities Associated with the Department's Plutonium Storage. DOE/EH-0415, Volume 1, Summary, and Attachment B, Vulnerability Summary Table. U.S. Department of Energy, Washington, DC.

DOE. 1996. Highly Enriched Uranium Working Group Report on Environmental, Safety and Health Vulnerabilities Associated with the Department's Storage of Highly Enriched Uranium. DOE/EH-0525, Attachment C, Vulnerability Summary Table. U.S. Department of Energy, Washington, DC.

DOE. 1998a. Richland Operations Office: Risk Prospectus - Hanford Site. U.S. Department of Energy, Center for Risk Excellence, Argonne, Illinois.

DOE. 1998b. Nevada Operations Office: Human Health and Safety Risk Summary - Nevada Test Site and Off-Site Test Areas. U.S. Department of Energy, Center for Risk Excellence, Argonne, Illinois.

DOE. 1998c. Rocky Flats Field Office: Risk Summary - Rocky Flats Environmental Technology Site. U.S. Department of Energy, Center for Risk Excellence, Argonne, IL.

DOE. 1998d. Savannah River Operations Office: Risk Summary - Savannah River Site. U.S. Department of Energy, Center for Risk Excellence, Argonne, Illinois.

DOE. 1998e. Albuquerque Operations Office: Risk Summary - Pantex Plant, Sandia National Laboratories, and Los Alamos National Laboratory. U.S. Department of Energy, Center for Risk Excellence, Argonne, Illinois.

Droppo, JG, Jr., DL Strenge, JW Buck, BL Hoopes, RD Brockhaus, MB Walter, and G Whelan. 1989b. Mulitmedia Environmental Pollutant Assessment System (MEPAS) Application Guidance Volume 1 User's Guide. PNL-7216, Pacific Northwest Laboratory, Richland, Washington.

FR 31219-31243. EPA. July 16, 1982. U.S. Environmental Protection Agency, "Uncontrolled Hazardous Waste Site Ranking System, Appendix A. Subpart H of the National Oil and Hazardous Substance Contingency Plan.” Federal Register.

Hawley, KA and BA Napier. 1985. "A Ranking System for Mixed Radioactive and Hazardous Waste Sites in U.S. DOE." In Proceedings of the Fifth DOE Environmental Protection Information Meeting. CONF-841187, Volume 1. November 6-8, 1984, Albuquerque, New Mexico. U.S. Department of Energy, Washington, D.C.

Hawley, KA, RA Peloquin, and RD Stenner. 1986. Modified Hazard Ranking System for Sites with Mixed Radioactive and Hazardous Wastes - User Manual. PNL-5841. Pacific Northwest Laboratory, Richland, Washington. 
ICRP. 1959. Report of Committee II on Permissible Dose for Internal Radiation. Publication 2, International Commission on Radiological Protection, Pergamon Press, New York.

ICRP. 1979. Limits for Intakes of Radionuclides by Workers. Publication 30, International Commission on Radiological Protection, Pergamon Press, New York.

Napier, BA, RA Peloquin, DL Strenge, and JV Ramsdell. 1988a. Conceptual Representation. Volume 1 of GENII - The Hanford Environmental Radiation Dosimetry Software System. PNL-6584, Volume 1, Pacific Northwest Laboratory, Richland, Washington.

Napier, BA, RA Peloquin, DL Strenge, and JV Ramsdell. 1988b. User's Manual. Volume 2 of GENII The Hanford Environmental Radiation Dosimetry Software System. PNL-6584, Volume 2, Pacific Northwest Laboratory, Richland, Washington.

Napier, BA, RA Peloquin, DL Strenge, and JV Ramsdell. 1988c. Code Maintenance Manual. Volume 3 of GENII -The Hanford Environmental Radiation Dosimetry Software System. PNL-6584, Volume 3, Pacific Northwest Laboratory, Richland, Washington.

Rocky Flats safety analysis (RFETS 1997) cited on pg 29 (38/50), need full citation

Serne, RJ and M. Wood. 1990. Hanford Waste-Form Release and Sediment Interaction. PNL-7297. Pacific Northwest Laboratory, Richland, Washington. 


\section{Distribution}

No. of

Copies

\section{OFFSITE}

Peter R. Siebach (3)

DOE-CH

Building: 201

Argonne, IL 64039

Michael J. Barainca

EM-51/Germantown Building

U.S. Department of Energy

1000 Independence Ave., SW

Washington, DC 20585-1290

Stephen L. Domotor

EH-41/Forrestal Building

1000 Independence Ave., SW

Washington, DC 20585

\section{ONSITE}

60 Pacific Northwest National Laboratory

Robert D. Stenner (50) K3-54

Dennis L. Strenge K3-54

Matthew S. Elder

William B. Andrews $\quad$ K6-04

Terry L. Walton (5) K9-46

Gordon R. Bilyard K3-54

Kelvin L. Soldat K3-53

Distr. 1 